\title{
HACIA UNA HISTORIA SOCIAL DEL TRIBUTO DE INDIOS Y CASTAS EN HISPANOAMÉRICA. NOTAS EN TORNO A SU CREACIÓN, DESARROLLO Y ABOLICIÓN
}

\author{
Aaron Pollack \\ Centro de Investigaciones y Estudios Superiores \\ en Antropología Social-Sureste
}

INTRODUCCIÓN

$\mathrm{F}$ n este artículo comparto los primeros resultados de una Einvestigación más amplia que se centra en la historia social del tributo y de las llamadas contribuciones directas - que a menudo tomaron la forma de capitaciones aplicadas únicamente a los indígenas - del periodo republicano, en los territorios del actual estado mexicano de Chiapas y de la República de Guatemala. En el futuro próximo, espero publicar otro escrito que retome lo expuesto aquí para analizar qué ocurrió durante el siglo xix cuando, en muchos de los países y regiones hispanoamericanas, se aplicaron estas contribuciones. Al considerar que los sistemas fiscales nos pueden dar claves sobre diferentes atributos de las sociedades en las cuales están insertas y de las cuales son partes constitutivas, he indagado en la historiografía sobre

Fecha de recepción: 8 de febrero de 2015

Fecha de aceptación: 7 de julio de 2015 
algunas de las particularidades del tributo de indios y de castas que considero relevantes para entender su transformación en el siglo xIx y, de paso, cómo ha influido en las sociedades hispanoamericanas. Con el afán de delimitar un tema de estudio de por sí desbordante, he intentado sintetizar lo que la historiografía (sobre todo institucional, fiscal y social) demuestra sobre ciertos argumentos vinculados con el tributo, ${ }^{1}$ lo que inevitablemente ha significado darle menos importancia a otros aspectos merecedores de una atención mucho más fina. He buscado identificar los antecedentes del tributo en Hispanoamérica, entender cuáles fueron las modificaciones más importantes en su desarrollo y captar cómo llegó a eliminarse. En particular me he interesado en comprender el desarrollo de los estatus fiscales vinculados a categorías socioétnicas ${ }^{2}$ en Hispanoamérica y el proceso por medio del cual se intentó desvanecer esta forma de categorización con la eliminación del tributo y la creación de las contribuciones directas. He puesto atención especial en los esfuerzos realizados en diferentes épocas y espacios, por aplicar tasas de cobro que reflejen - de alguna manera - la capacidad económica del tributario.

Por otro lado, he escogido dar menos énfasis a aspectos como la función del tributo para asegurar el trabajo indio;

${ }^{1}$ A lo largo del artículo se menciona una bibliografía amplia sobre el tema, pero algunos de los estudios clásicos merecen una mención aquí: Miranda, El tributo indígena; Gibson, Aztecs; Díaz Rementería, "En torno" y "El régimen"; Sánchez Albornoz, Indios. Aportaciones recientes e importantes incluyen Sala I VILA, Y se armó; Marino, "El afán”; Granados, "Cosmopolitan”, y Terán, Tributos.

${ }^{2}$ En diferentes periodos durante la colonia, a estas categorías solían referirse con los términos de "clases" o "calidades", los cuales también utilizo en este artículo. 
el vínculo entre el tributo y el acceso a la tierra; las acciones fraudulentas en torno al tributo, que fueron sin duda una constante a lo largo de su existencia; las implicaciones que la evasión del tributo tuvo para la movilidad de los tributarios y para la recolección del mismo; los servicios personales como forma de tributo y las obvenciones religiosas. Por otra parte, me he referido apenas al siglo XvII; ${ }^{3}$ no he podido ni considerar la posibilidad de incluir los aspectos más cuantitativos dentro del análisis, y lamento que el artículo sufra de grandes sesgos geográficos, con pocas referencias a varias partes de Hispanoamérica y ninguna mención de otras; las particularidades de Filipinas y mis propias limitaciones en cuanto a la posibilidad de abordarlas me han persuadido de no incluirlas en el análisis. ${ }^{4}$

El artículo comienza con una discusión sobre algunos de los cobros fiscales aplicados en el reino de Castilla que pueden asemejarse al tributo indiano. Posteriormente se discuten las distinciones sociales que el tributo de indios y de castas estableció o fortaleció, el vínculo entre la exención del tributo y la participación militar, y la importancia que tuvieron los esfuerzos para fortalecer el poder de la monarquía durante la temprana modernidad en el establecimiento del sistema de tributos. En seguida se consideran brevemente algunos aspectos del pensamiento económico del siglo xviII y las reformas a los mecanismos de cobro del tributo que se implementaron a partir de 1769. El artículo termina con una discusión

${ }^{3}$ Cabe mencionar la importancia de los mecanismos sumamente abusivos del cobro del tributo desarrollados en Chiapas en el siglo xvir y que después fueron una de las razones principales detrás de la rebelión de los zendales en esta provincia en 1712. ViqueIRA, "Tributo y sociedad". ${ }^{4}$ Relativo al tributo en Filipinas, puede consultarse Alonso Álvarez, "El tributo” y “QQué nos queréis?”. 
más amplia de los diferentes aspectos que influyeron en las decisiones para eliminar el tributo en Hispanoamérica y los primeros intentos por imponer una contribución directa.

Antes de avanzar, considero importante señalar la existencia de grandes diferencias entre los virreinatos, capitanías generales y audiencias hispanoamericanas y también la heterogeneidad en su interior, lo que dificulta la generalización e, inevitablemente, ha hecho que los esfuerzos por avanzar en una discusión que compare y contraste estas regiones queden bastante cortos. No obstante esta dificultad, estimo necesario explicitar, para las discusiones que aquí se abordan, algunas diferencias básicas que son relevantes entre la región andina y la que incluye a México y Centroamérica.

Son tres distinciones importantes entre estas dos regiones las que atañen a esta investigación, más allá de las muchas diferencias dentro de cada una. En primer lugar existe una opinión académica relativamente uniforme, si bien matizada y cuestionada, sobre el hecho de que desde el periodo incaico $-\mathrm{O}$ antes en algunos lugares - hasta el siglo XIX (e incluso el siglo xx en ciertos casos), muchos de los pueblos andinos consideraron que al pagar una forma de tributo a los gobernantes incas y españoles, o posteriormente los impuestos de capitación a los gobiernos republicanos, se aseguraban el acceso a la tierra. ${ }^{5}$ En el caso de la región mesoamericana, hay menos datos que sustenten este supuesto y, por tanto, menos uniformidad en la opinión académica relativa a la existencia de este entendimiento. ${ }^{6}$

\footnotetext{
5 Con esta afirmación no se quiere implicar que toda la población andina dependía de la agricultura para sus ingresos principales, pues alguna parte de ella se sustentaba de otras actividades económicas como el comercio y la artesanía.

6 Se retomará esta discusión más adelante.
} 
En segundo lugar, más allá de las distinciones estamentales (indio, español, mestizo, mulato, negro, zambo, casta, libre de color, etc.) utilizadas por la corona española en los territorios americanos, algunas de las cuales se mantuvieron en ciertos países - notablemente para fines fiscales-, durante buena parte del siglo XIX, en la región andina los originarios, forasteros y yanaconas (o conciertos en la Audiencia de Quito) formaban categorías específicas dentro de las clasificaciones más amplias de "indio" y, después, "indígena". Todas estas categorías, que sirvieron en su momento para fines fiscales y jurídicos, siempre demostraron grados de flexibilidad, en especial en ciertos lugares y momentos históricos, por lo que es menester resaltar el amplio espectro humano encerrado en cada una de ellas. ${ }^{7}$

Como primera distinción entre estas tres categorías, los originarios y forasteros, habitantes de las comunidades o ayllus, tenían la responsabilidad de realizar el servicio personal (mita), pero a los yanaconas, atados de manera perpetua a las haciendas españolas - que se encargaban de pagar su tributo- y desvinculados de los ayllus, no les correspondía esta obligación. En la Nueva España a los indios que vivían y trabajaban en haciendas también se les conocía por clasificaciones fiscales particulares, ${ }^{8}$ aunque las referencias a esas categorías son menos frecuentes.

\footnotetext{
7 Véase Solano, "La construcción” y "Padrones”, para una discusión sobre la difícil y complicada utilización de estas categorías en Hispanoamérica y en particular en el Nuevo Reino de Granada.

8 Sánchez Santiró menciona los "vagos" y "laboríos”. Sánchez SANtiró, Corte de caja, p. 142. Silva Riquer argumenta que los "naboríos" o "laboríos" aparecieron en la documentación novohispana en el siglo XVIII, entendidos como grupos de trabajadores que se movían de lugar en lugar, según las posibilidades laborales que se presentaban. SiLva RiQUeR,
} 
La segunda distinción, entre originarios y forasteros - categorías inexistentes en los territorios que ahora forman Centroamérica y México-, así como se entendía en la segunda mitad del siglo xvinI, hacía referencia a la diferenciación entre aquellos indios con plenos derechos y obligaciones comunitarios (los originarios) y otros con derechos y obligaciones diferenciados (los forasteros). Los primeros formaban parte de la colectividad que poseía la tierra y pagaban una tasa más alta de tributo; los segundos estuvieron presentes en las comunidades como arrendatarios (y a veces sin acceso a la tierra) y pagaban una tasa de tributo menor. ${ }^{9}$ Aunque los forasteros podían estar presentes en una comunidad por generaciones o bien podían ser hijos

"El trabajo indígena”, p. 27. Fonseca y Urrutia se refieren a los "indios laboriosos", que se entiende como "gañanes y sirvientes de otros vasallos", quienes estuvieron exentos del pago de los cuatro reales y medio (conmutado de la media fanega de maíz, uno de los cobros establecidos en el intento inicial de uniformizar la tasa de tributos hacia finales del siglo xvi, al que se referirán más adelante) que debían los demás tributarios. Fonseca y URrutia, Historia, t. 1, pp. 432-433.

9 En el norte de Potosí, la condición de originario se definía más por tener acceso a parcelas en diferentes zonas ecológicas, que los forasteros no tenían, y menos por cuestiones genealógicas. SERulnikov, "De forasteros”, p. 50. Para una discusión amplia sobre los cambios en el significado de los términos forastero y yanacona, como también en los de agregado y vago, véase la explicación de Sánchez Albornoz, Indios. En la Nueva España y el reino de Guatemala el término forastero se refería a las personas que habían dejado sus pueblos de origen, pero no se utilizaba como una clasificación tributaria que describiera a miembros permanentes de las comunidades de destino. Podría ser interesante, para futuras investigaciones, comparar el desarrollo de la categoría ladino en Centroamérica y Chiapas con la de forastero en la región andina. 
de originarios, el sistema andino no preveía su conversión en originarios, aunque a veces ocurrió. ${ }^{10}$

La tercera diferencia fundamental, aunque en este caso se trata aún más claramente de una generalización, se refiere al hecho de que para el siglo XviII, si no antes, en la región andina los curacas y caciques, en especial antes de la Gran Rebelión (1780-1781) y la implementación del sistema de intendentes, ${ }^{11}$ tenían características diferentes de las de sus semejantes de la región mesoamericana. Los curacas sudamericanos no sólo tuvieron más importancia en el gobierno territorial y en la recaudación del tributo, sino que también destacaron, por su importancia simbólica y presencia en la vida pública, precisamente como indios nobles, aun en las grandes ciudades. En contraposición, para el siglo XviII, los caciques en la Nueva España y el reino de Guatemala tenían un papel mucho menos importante como figuras públicas y también como gobernantes locales pues, tras un proceso de nivelación social, este papel y el de recolectar el tributo habían pasado, en mayor o menor grado, a manos de los cabildos. ${ }^{12}$

10 Serulnikov recuenta el paso de forastero a originario en el caso de una familia inmigrante que gozaba de una condición económica muy favorable. Serulnikov, "De forasteros”. Hidalgo ofrece un ejemplo: indios, catalogados como tributarios en un pueblo, que vivían en otro por muchos años sin volverse forasteros, pagando el tributo en su lugar de origen; en este caso, las presiones fiscales y de los curas a mediados del siglo XVIII forzaron la recategorización como forasteros en su lugar de residencia. Hidalgo, "Complementariedad".

11 Sobre los cambios en torno al paso de caciques hereditarios a caciques de otras naturalezas, a menudo españoles, en las intendencias de Cuzco y Puno entre 1780 y 1825, véase CAHILl, From Rebellion, pp. 153-168. 12 Díaz Rementería esgrime este argumento. Díaz Rementería, “El régimen”, p. 417. 
DEL PORQUÉ EL TRIBUTO DE INDIOS Y CASTAS NO TENÍA PARALELO EN CASTILLA ${ }^{13}$

El tributo de indios y de castas, tal y como se aplicaba en los territorios americanos de la Monarquía española, tenía características particulares que resultaron de la forma y el momento de su aplicación inicial, y éstas lo distinguían de otros cobros de la época dentro de la Monarquía. El tributo de indios nació como una fuente de ingresos para el rey de Castilla proveniente de su dominio señorial, pero también, y de manera significativa, como mecanismo para demostrar que los indios eran vasallos de él y no de los conquistadores: fungió como parte de los esfuerzos para eliminar cualquier posibilidad de que en América se crearan señoríos territoriales como los que contemporáneamente en Europa iban renegociando sus privilegios ante un proceso de fortalecimiento de las monarquías que se ha denominado como la creación de los "estados modernos". ${ }^{14}$

En el paso del bajo medievo a la temprana modernidad, las monarquías cum "estados modernos" cambiaron de manera clara sus sostenes fiscales principales: en vez de vivir de los ingresos provenientes de sus propios dominios señoriales $-\mathrm{y}$ solicitar fondos especiales ante los parlamentos, estados, dietas o cortes en caso de guerra-, las crecientes necesidades estatales comenzaban a satisfacerse por medio de otras rentas, como esbozó hace casi un siglo Schumpeter, cuando distinguió el "Estado de dominio territorial" del

${ }^{13}$ Esta discusión se refiere al reino de Castilla porque los territorios hispanoamericanos se integraron a él jurídicamente a partir de 1519, por lo que ofrece el referente más obvio.

${ }^{14}$ Schulze, "The Emergence”, p. 264. 
"Estado fiscal". ${ }^{15}$ Dejando atrás el supuesto medieval de que los reyes debían vivir de sus propios fondos, por lo menos en tiempos de paz, ${ }^{16}$ en este periodo las monarquías iban aumentando su capacidad de recaudación, ante los incrementados gastos de guerra asociados especialmente al mantenimiento de un ejército permanente $y$, aunque en un plano secundario, los complementarios costos adicionales relacionados con las burocracias fiscales que debieron establecerse para recaudar fondos de manera constante. ${ }^{17}$

A diferencia de lo que había sido común a principios del siglo Xvi, para finales de la centuria los reyes europeos, y ya no sólo los señores, se beneficiaban de los excedentes producidos por economías todavía predominantemente

15 Schumpeter, "La crisis", pp. 151-163.

16 Gelabert, "The Fiscal Burden", pp. 542-543.

17 En el reino de Castilla, los derechos provenientes del dominio real no ofrecían aportes significativos al erario real desde mediados del siglo xIv. Ladero Quesada, "Estructuras”, pp. 124-125. En décadas recientes muchos investigadores han definido al Estado moderno, en especial en el periodo anterior al desarrollo de estados de bienestar y socialistas, como estados fiscal militares. Brewer, The Sinewes; Tilly, Coercion; Bonney, Economic; Storrs, "Introduction"; Caravaglia, “Algunos”. Aunque hay autores que cuestionan la pertinencia del término "Estado" para referirse a la Monarquía española durante la temprana modernidad, la noción del Estado fiscal militar sirve para subrayar la importancia de las funciones primordialmente militares del Estado (y de la Monarquía española), así como la importancia de una estructura fiscal que permitiera el desarrollo de estas funciones. Respecto al debate sobre el uso del término "Estado" para referirse a la Monarquía española, véase Schaub, "La penisola”; Lempérière, “Reflexiones”; García Pérez, “Modernidad”. Sobre la relación negociada que el rey mantenía con los territorios americanos, y por tanto, un argumento que fortalece la noción de una monarquía española sin suficiente centralización para considerarse un Estado, véase GRAFE e IRIGoÍn, “A Stakeholder”. 
agrarias, ${ }^{18}$ tal y como el monarca castellano y los encomenderos recibían los tributos de los indios americanos, pero con una importante diferencia. Al insistir en que el tributo que recibieran los encomenderos se entendiera como un premio que el monarca les otorgaba de manera provisional, y que las encomiendas no fueran territoriales (es decir, que implicaran el control sobre un territorio), ${ }^{19}$ el rey castellano logró asegurar que los encomenderos no se volvieran señores al estilo europeo. ${ }^{20} \mathrm{~A}$ la vez, al asignarse la mayor parte del tributo para ellos mismos - como derechos señoriales -, los monarcas se garantizaron una fuente de ingresos que correspondía a sus propios dominios (como también lo eran el quinto y luego el diezmo real): una fuente de ingresos que iba perdiendo importancia en varias partes de Europa en la medida en que los monarcas vendían sus dominios señoriales para cumplir con las ascendientes necesidades fiscales, como se ha dicho, principalmente asociadas con los gastos militares. ${ }^{21}$

En el reino de Castilla existieron varios cobros que de alguna manera se han comparado con el tributo de indios y de castas, pero ninguno de los derechos señoriales cobrados en Castilla durante el periodo de la dominación española en América, es decir, contemporáneamente con el tributo,

18 Schulze, “Emergence”, p. 276.

19 Sobre el desarrollo de las encomiendas americanas véase Dougnac Rodríguez, Manual, pp. 332-360.

20 A partir de las Nuevas Leyes de 1542, se decretó la abolición de la provisión de los servicios personales de los indios a los encomenderos, de manera que el tributo de indios era el único beneficio - por lo menos por derecho, pues en la práctica los servicios personales continuaron - que las encomiendas les ofrecían a sus detentores.

21 Bonney, “Revenues”, p. 463; 't Hart, “The Emergence”, p. 284. 
consideraba un cobro económicamente significativo para los pecheros. ${ }^{22}$ En las siguientes líneas se abre una discusión sobre estos cobros para demostrar cómo se diferenciaban del tributo y así acercarnos a las particularidades de éste y su papel en la formación de las sociedades americanas.

Durante los siglos que mantuvo sus colonias americanas, el rey percibía de sus territorios castellanos un ingreso conocido como el "servicio", que derivaba en parte de "tradiciones alto medievales o en el cobro de derechos feudales sobre los vasallos y dependientes”, que se comenzó a legitimar con "nuevos principios políticos que justifica[ba]n la imposición directa universal por causa de 'necesidad urgente' o dificultad especial”. ${ }^{23}$ En el siglo Xvi, contemporáneamente con la conquista y el establecimiento del sistema del tributo de indios, en Castilla los reyes debían asegurar la aprobación de las Cortes para poder cobrar el servicio, generalmente mediante negociaciones en las cuales éstas recibían algunos beneficios a cambio de su anuencia. ${ }^{24}$ Después de la Guerra de las Comunidades de Castilla entre 1520 y 1522, Carlos V entró en un periodo de negociaciones

${ }^{22}$ Las regalías que los judíos, en su condición de servi camarae, pagaban a los reyes castellanos antes de la expulsión de 1492, se asemejaban más al tributo de indios y castas por ser un derecho (aunque correspondía al rey, no al señor). LADERo Quesada, “Estructuras”, pp. 124-125.

${ }^{23}$ Ladero Quesada, "Estructuras”, p. 133. Sobre los servicios, véase Angulo Teja, La Hacienda española, p. 138.

${ }^{24} \mathrm{La}$ importancia del papel del tercer estado para la aprobación de los servicios a pagar no debe subestimarse pues desde mediados del siglo xvI, de los tres estados que formaban las Cortes de Castilla, sólo el tercero se reunía; se consideró innecesaria la presencia de los otros dos brazos en la medida que ellos no tuvieron la obligación de autorizar estos ingresos reales. 
constantes con las Cortes castellanas e implementó una serie de reformas que éstas proponían, pues el reino dependía de ellas para la mayor parte de sus ingresos y el emperador las necesitaba, además, como seguridad para los préstamos que le permitieran realizar sus muy variadas actividades. ${ }^{25}$

Una vez que en las Cortes de Castilla se definía el monto total que el tercer estado se comprometía a pagar al monarca en calidad de servicios, se procedía a especificar la cantidad que cada una de las diferentes ciudades, villas y distritos administrativos debía aportar. Como siguiente paso, dentro del concejo (en muchos de los casos) de cada población se decidía cómo se distribuiría la carga tributaria entre los pobladores. Según el interesante trabajo de Romero Martínez, aunque los sistemas de cada lugar tenían sus particularidades, lo más común era que el concejo (u otra autoridad) estableciera diferentes rangos que correspondían a cantidades a pagar según el valor total de los bienes de cada pechero. ${ }^{26}$ De lo anterior se aprecia que - independientemente de sus orígenes - en el siglo Xv, si no antes, estos impuestos se cobraban con una tasa que variaba según la capacidad económica y, adicionalmente, que el mismo concejo - o en todo caso personas del mismo poblado o distrito - tasaba el valor de los bienes. ${ }^{27}$

25 Espinosa, “The Spanish Reformation”. Owensby ha notado que las reformas adoptadas a raíz de la revuelta comunera transformaron al gobierno español en el momento en que su imperio de ultramar comenzaba a establecerse. Owensby, "Pacto", p. 65.

26 Romero, "Proceso". Este sistema se mantuvo hasta el siglo XviII. Guasti, “Clergy”, p. 32.

27 Este sistema es muy similar a la manera en que varias de las ciudades-estado italianas cobraban ciertos impuestos directos en el siglo xv, aunque los sistemas italianos eran aún más complejos y podían incluir la 
Con el avance del siglo xvi, la capacidad de negociación de las Cortes se redujo paulatinamente, aunque éstas siguieron aprobando una buena parte de los ingresos fiscales necesarios para los reyes españoles: los servicios resultaron "ordinarios" en el sentido de que no requerían de la aprobación especial de las Cortes, se comenzaron a cobrar los servicios extraordinarios (los cuales perdieron su calidad de extraordinariedad) y posteriormente se aplicó el servicio de los millones en 1591, que las Cortes sólo aprobaron después de negociaciones en las que se acordó el mecanismo a usarse para administrar su cobro. ${ }^{28}$ Para el siglo XviII, y aun hasta el siglo xIx, los servicios ordinarios, extraordinarios y el servicio de los millones se cobraban dentro de un conjunto de impuestos conocido como rentas provinciales, entre las cuales se encontraban muchos otros (la alcabala figuraba como uno de los más importantes): algunos generales, unos cobrados de manera excepcional y otros cobrados sólo en ciertas provincias castellanas. ${ }^{29}$ Desde antes del siglo XVI - el momento en que el tributo comenzó a cobrarse en las Indias -, los servicios no podían considerarse un derecho señorial debido a que en el transcurso de los siglos

elaboración de catastros. En los dos casos se hacían listados de los bienes de los tributarios. Bonney, "Revenues", p. 473; DeAn, "Wealth". La graduación en la cantidad cobrada, en este caso no según el valor de los bienes poseídos sino por el estatus (sirvientes, artesanos), se había utilizado en la segunda y la tercera aplicación de los impuestos de capitación (poll tax) en Inglaterra en 1377, 1379 y 1381. GolDBERG, "Urban".

${ }^{28}$ Fortea Pérez, "Reino".

29 Angulo Teja, "Los ingresos”, n. 1, pp. 481-482; González EnCIso, "La Hacienda castellana", p. 26. La reforma por medio de la cual se comenzaron a cobrar conjuntamente las rentas provinciales se realizó entre 1669 y 1691. GonzÁlez Enciso, "La Hacienda castellana”, p. 26. 
anteriores los cobros originalmente entendidos como derechos, y que se integraron a las rentas provinciales, ya no se justificaban como tales.

A partir de finales del siglo xIv, el rey de Castilla cobraba a los judíos (hasta su expulsión en 1492) y los mudéjares (hasta su conversión en 1502) el impuesto conocido como el "servicio y medio servicio". A partir de 1482, la corona comenzó a cobrar a los adherentes de estas religiones los “castellanos de oro" para sufragar la guerra en Granada y, a partir de 1492, se siguió con el mismo cobro a los mudéjares con el nombre de "pechas". ${ }^{30}$

En el reino de Granada, después de la reconquista, los moriscos pagaban una especie de servicio, conocido como la farda mayor. Igual que el "servicio y medio servicio", los “castellanos de oro” y las regalías que pagaban los judíos, la farda se parecía al tributo de indios y castas por aplicarse con base en criterios "étnicos" o religiosos. ${ }^{31}$ A diferencia del tributo de los indios y castas, el cobro total de la farda mayor se negociaba, como ocurría en las Cortes castellanas,

30 ViÑuAles, “El repartimiento”, pp. 179-181.

31 Castillo Fernández, “Incidencia”, pp. 214-215. Históricamente, los criterios basados en la etnicidad o en diferencias religiosas, a menudo en contextos de colonización, se han aplicado en muchas ocasiones para delimitar diferencias en las condiciones tributarias. Sin el afán de presentar un listado exhaustivo de estos casos, resulta pertinente notar el cobro de la jizya a los dimmi (cristianos, judíos y otros no islámicos) en territorios musulmanes, los impuestos que pagaban los judíos en la Europa del bajo medievo y temprana modernidad, las formas tributarias adoptadas por los poderes metropolitanos durante el siglo xx en África colonizada. Sobre la jizya véase Fattal, Statut, pp. 264-343; Ahmed y Ahmad, “The Concept”. Sobre lo cobrado a los judíos, consúltese LADERO QUESADA, “Estructuras”, pp. 124125. En torno a la experiencia africana, pueden verse Cullen, "East African”; Arowolo, “The Taxation”, p. 327; Baker, “Tax”; Jamal, “Taxation”. 
entre los líderes moriscos y la monarquía; asimismo, como sucedía con los servicios castellanos, se cobraba con tasas que variaban según el nivel de riqueza y propiedades. Los moriscos compartían, o por lo menos así se podría argumentar, una condición similar a la de los indios y castas en América - como veremos más adelante - porque ellos pagaban la farda mayor mientras los cristianos viejos recibieron exención de la misma, ${ }^{32}$ tal y como los españoles y mestizos en América fueron exentados del pago del tributo y también de los servicios (que, como veremos, nunca se aplicaron en Hispanoamérica).

La moneda forera, pagada en el bajo medievo y la temprana modernidad en el reino de Castilla, se asemejaba al tributo americano, como han referido varios autores: Castañeda, Haring, Menegus y Mörner, principalmente porque se aplicaba a los pecheros en reconocimiento de su estatus de vasallos y, en un segundo plano, por su aplicación con una tasa única en forma de capitación. ${ }^{33}$ A diferencia del tributo americano, que se cobraba dos o tres veces al año a una tasa que resultaba ser significativa para las bolsas de los vasallos, la moneda forera se pagaba una vez cada seis o siete años y su valor a mediados del siglo XviI, según Solórzano Pereyra, era de medio real. ${ }^{34}$ La moneda forera, entonces, se asemejaba

32 Castillo Fernández, “Incidencia”, p. 214.

33 Castañeda Delgado, "Un problema”, pp. 509 y 543; Haring, El imperio, p. 371; Menegus Bornemann, "Alcabala", pp. 110-111; MörNER, La corona española, p. 94.

34 Ladero Quesada, "Estructuras”, p. 134; Castillo Rubio, “Tejido", pp. 238-240. Es de subrayarse que Solórzano Pereira es citado con frecuencia como referencia para la comparación entre la moneda forera y el tributo, pero raramente se menciona que el mismo autor indica la poca frecuencia del cobro y su diminuto importe. Solórzano Pereyra, 
al tributo en cuanto derecho señorial y su aplicación en forma de capitación, pero se diferenciaba mucho en el impacto económico que tuvo para los vasallos que lo pagaban.

La martiniega fue otro cobro castellano que a veces se ha considerado similar al tributo americano. ${ }^{35}$ Como en el caso de la moneda forera, la justificación fue el principal aspecto de la martiniega que se le asemejaba al tributo: fue un reconocimiento del dominio ajeno que pagaban los cultivadores. Para el siglo xviII, el cobro de la martiniega era de apenas 12 maravedíes anuales, menos de medio real. ${ }^{36}$

Como Cobá Noh y Granados han hecho ver, a principios del siglo XIX, por lo menos algunas autoridades españolas tenían claridad sobre la unicidad del tributo americano: el tributo de los "indios, negros y mulatos es original y único de América, que tuvo su ejemplo en los emperadores de la Europa y su principio en los incas y moctezumas". ${ }^{37}$

\section{EL ESTABLECIMIENTO DEL TRIBUTO DE INDIOS}

En América, el tributo indio y el de castas se justificaron, a lo largo del periodo colonial, como un derecho entregado en muestra de vasallaje que los incas y Moctezuma cedieron

Política, vol. 1, libro II, cap. XIX, núm. 38. El cobro de la moneda forera se extinguió en 1724. Pérez León, "Hidalgos”, p. 66.

35 Solórzano Pereyra, Política indiana, vol. 1, lib. II, cap. XIX, núm. 39; Совá NoH, El “indio ciudadano", p. 74.

36 Angulo Teja, La Hacienda española, p. 157.

37 Dictamen de la Mesa de Memorias y Alcances sobre la duda de la calidad de tributarios de los expósitos, Mesa de Memorias y Alcances de la Contaduría Mayor del Tribunal y Audiencia de Cuentas de México, $1^{\circ}$ de agosto de 1800, citado en Granados, "Cosmopolitan”, p. 146; Совá NoH, El “indio ciudadano”, p. 74. 
al rey de Castilla, ${ }^{38}$ y las autoridades españolas definieron la cantidad a pagarse sin la mediación de instancias como las Cortes de Castilla, que negociaban las cantidades que el tercer estado castellano pagaba en calidad de servicios. El tributo de indios no siempre se cobraba con los mismos sistemas que antes habían utilizado los gobernantes locales. En los actuales territorios de México y Centroamérica, en los años previos a la conquista española, los súbditos entregaban el tributo en especie y en servicios personales, ${ }^{39}$ pero en la región andina - con la excepción del altiplano del actual Ecuador $-{ }^{40}$ las obligaciones tributarias se cumplían, con pocas excepciones, por medio de labores (entre ellas la mita). ${ }^{41}$ El tributo español cobrado en bienes y servicios personales - que en un inicio correspondía a los encomenderos - no modificó mucho los sistemas previamente aplicados en el norte, pero en el sur provocó resistencia porque la entrega de tributo en especie rompía de forma radical con la costumbre en la mayor parte del imperio incaico. ${ }^{42}$

${ }^{38}$ Existía también el argumento, vigente por lo menos en el siglo xvI, sustentado por las órdenes mendicantes, de que el rey de Castilla tenía el derecho de cobrarles el tributo a los indios con tal de que se les evangelizara. Menegus, "La iglesia de los indios”, p. 114. Es decir, que la justificación para el cobro del tributo devenía de las bulas alejandrinas que permitieron la conquista de América a condición de realizar la evangelización, así no de la cesión de derechos por parte de Moctezuma y el Inca. 39 Miranda, El tributo indígena, p. 26; Hassig, Comercio, p. 119.

40 En el altiplano ecuatoriano, desde antes del periodo incaico, a diferencia del centro y sur de los Andes, la presencia de comerciantes y de mercados permitía que los señores locales cobraran tributo en bienes. D’Altroy y Earle, “Staple”, p. 195.

${ }^{41}$ Murra, “Did Tribute”, 1995; D’Altroy y Earle, “Staple”, p. 189.

${ }^{42}$ Murra, "Did Tribute" pp. 59-60. Un observador español del siglo Xvi notó que los indios peruanos resentían más que se les exigiera un costal 
Los habitantes de los territorios americanos vieron reducirse la diferenciación fiscal con la implementación del sistema español, tal y como los inmigrantes peninsulares observaban - como se verá en las próximas páginas - el desvanecimiento de los tres estados en las Indias. En los imperios de los incas y de la Triple Alianza, como también en los territorios k'iche', tz'utujil (los dos se ubican en la actual Guatemala) y tseltal (hoy Chiapas), la sociedad se dividía entre los vasallos que cumplían con sus obligaciones tributarias, y los nobles y señores, exentos del tributo, que se beneficiaban de los bienes y trabajo que se les entregaban. ${ }^{43}$ Además de los señores y nobles, en los territorios mexicas y en el altiplano guatemalteco, algunas personas dedicadas a ciertos oficios parecen haber gozado de una exención del tributo. ${ }^{44}$ Otras personas, como los tlaimaites y los mayeques en el Valle de México, tributaban a los señores locales y no tenían responsabilidades fiscales ante los gobernantes de la Triple Alianza. ${ }^{45}$

Según Miranda y Gibson, los labradores, artesanos y comerciantes en los territorios de la Triple Alianza pagaban diferentes tipos de tributo, lo que correspondía, a grandes rasgos, a lo ocurrido entre los k'iche's en el altiplano

de papas que se les impusiera un trabajo de 15 días con la comunidad. "Informe al licenciado Briviesca de Muñatones", escrito por Polo Ondegardo en 1562, citado en Murra, "Did Tribute”, p. 59.

${ }^{43}$ Miranda, El tributo indígena, p. 26; CARMack, Quiche, pp. 148-155; Orellana, Tzutujil, pp. 63-67; Zamora Acosta, Los mayas, pp. 206210; Ruz, Copanaguastla, pp. 285-288.

${ }^{44}$ Miranda, El tributo indígena, p. 26; Zamora Acosta, Los mayas, p. 206.

${ }^{45}$ Gibson, The Aztecs, p. 154. 
guatemalteco. ${ }^{46}$ En el territorio mexica, los labradores se responsabilizaban por diferentes cantidades de tributo, de manera que hubo bastante diferenciación dentro de cualquier colectividad. ${ }^{47}$ Bajo los incas, donde la mayoría del tributo consistía en la labor prestada al Estado, parece que la distribución de los turnos en la mita haya sido más uniforme dentro de cualquier ayllu. ${ }^{48}$ Sin embargo, en algunos casos los comerciantes pagaban impuestos cuyos montos dependían del tipo de actividades que realizaban: antes del periodo incaico, en los territorios del altiplano ecuatoriano, los comerciantes entregaban un tributo que se calculaba como una porción de los bienes que intercambiaban; ${ }^{49}$ por otra parte, entre los lupaqa, alrededor del lago Titicaca, los dueños de las caravanas pagaban una especie de tarifa, pagada con algunos de los bienes adquiridos durante sus recorridos, por el permiso que autorizaba sus viajes comerciales. ${ }^{50}$

En la Nueva España, aún en el siglo xvi, se mantuvieron vigentes los diferentes cobros que anteriormente correspondían a los señores locales, además del tributo que ahora se pagaba a la corona o a los encomenderos - sin mencionar

${ }^{46}$ Miranda, El tributo indigena, p. 26; GIBson, The Aztecs, p. 198; CARMACK, The Quiche, pp. 149-155.

${ }^{47}$ Miranda, El tributo indígena, pp. 24-34; Gibson, The Aztecs, p. 196, 198. Algunos autores del siglo xvi han indicado que en Chalco y Texcoco los labradores tributaban en proporción a las tierras que tenían. Aunque Miranda no comparte esta interpretación, Gibson la acepta ampliamente. Miranda, El tributo indígena, n. 88, pp. 32-33; Gibson, The Aztecs, n. 23, p. 518.

${ }^{48}$ La Lone y La Lone, “The Inka State”, p. 53.

49 D’Altroy y Earle, “Staple”, p. 195.

50 Browman, "Comments", p. 197. 
las obvenciones eclesiásticas - ${ }^{51}$ En este periodo, en algunos lugares de la Nueva España, se cobraba una capitación graduada y en otros una capitación uniforme, ${ }^{52}$ pero entre 1577 y 1606, se definieron tasas universales (aun si nunca se logró aplicarlas en la práctica) para los tributarios enteros,$^{53}$ que debieron aplicarse de manera igual en todo el territorio novohispano: cuatro reales de la contribución de comunidad, un pago "casi uniforme" del tributo equivalente al valor de un peso y media fanega de maíz, cuatro reales de servicio, medio real para el sostenimiento del juzgado general de indios (conocido como de ministros) y medio real para la edificación de la catedral metropolitana. ${ }^{54} \mathrm{~L}$ diversidad entre diferentes lugares era la regla a lo largo del periodo colonial en la Nueva España y, para los siglos XVIII y XIX, había variaciones muy fuertes (de 4 a 24 reales anuales $)^{55}$ entre los tributarios que vivían en comunidades, mientras los indios que trabajaban y vivían en los

${ }^{51}$ Spores, The Mixtec, pp. 157-164; Miranda, El tributo indigena, pp. 24-25; Gibson, The Aztecs, p. 44.

${ }^{52}$ SÁnchez Santiró, Corte de caja, p. 141.

${ }^{53}$ El tributario entero se conceptualizaba, en general, como un hombre y su esposa, es decir, un matrimonio, lo que definitivamente lo distingue del contribuyente en los sistemas republicanos y asimismo invita a pensar sobre su impacto en el patriarcado en Hispanoamérica. Granados, “Cosmopolitan", pp. 113-116. Existía también la categoría de "medio tributario" que podía, en diferentes momentos y lugares, referirse a, entre otras cosas, viudos/viudas, solteros/solteras, forasteros andinos sin tierra - mencionados anteriormente-, o indios recientemente congregados. Díaz Rementería, "En torno”, p. 55; Sánchez Santiró, Corte de caja, p. 141.

${ }_{54}$ Miranda, El tributo indígena, pp. 18-20.

${ }^{55}$ Marino, "El afán”, p. 73. 
ranchos, en condiciones similares a los yanaconas andinos, pagaban el tributo a una tasa menor. ${ }^{56}$

La decisión tomada por las autoridades españolas en la Nueva España de establecer un cobro uniforme - o más bien, establecer un mínimo y un rango mayor de poca diferencia - se sustentó en el argumento de que era necesario contrarrestar los abusos presentes en el sistema anterior, en que se había buscado definir la tasación de cada pueblo de indios con base en su posibilidad de pagar según las condiciones locales. ${ }^{57}$ Esta decisión de uniformar los cobros generó mucha discusión durante el tercer cuarto del siglo xvi sobre si el tributo debía ser personal (por persona, sin distinguir) o bien real (variable, según los bienes de las personas tasadas),${ }^{58}$ lo que habría sido más afín al sistema vigente en los pueblos de la Península en aquel entonces, además de ser más similar - o por lo menos así parece - al sistema imperante antes de la conquista en los territorios de la Triple Alianza. No obstante la discusión sobre lo injusto que era el cobro casi uniforme, esta elección se mantuvo vigente porque se consideraba muy difícil realizar una valoración adecuada de los bienes de cada indio y se temía una

${ }^{56}$ Sánchez Santiró, Corte de caja, p. 142; Marino, “El afán”, pp. 63-64. ${ }^{57}$ Miranda, El tributo indígena, p. 159. En el reino de Guatemala, por lo menos hasta 1584 se aplicaban dos formas de tributo: uno personal y otro real, tasado según la posibilidad de pago que la producción agrícola permitía. Orellana, The Tzutujil, p. 154.

${ }^{58}$ Miranda, El tributo indígena, pp. 149-152 y 165-168; Jáuregui, "De re tributaria", p. 11. Claramente, este debate se desarrolló en el contexto demográfico de una reducción drástica de la población india, lo que probablemente influyó en las diferencias económicas dentro de los pueblos y en la discusión sobre la forma más adecuada de tasar a los tributarios. 
intervención poco honesta por parte de los caciques, ${ }^{59}$ quienes habrían sido los consultados para realizarla, tal y como los concejos, o quienes por ellos lo hacían en Castilla.

En la práctica, sin embargo, como han indicado Fonseca y Urrutia, Maniau, Gibson y Marino, ${ }^{60}$ en la Nueva España el cobro de los tributos variaba enormemente entre los diferentes pueblos, con tasas que en un inicio se elaboraron al conmutar "en dinero al respecto de los frutos que contribuyan desigualmente ó de valores distintos, sobre lo que no se sabe otra cosa que haberse establecido así desde los primeros tiempos del arreglo de este ramo en el siglo diez y seis". ${ }^{61}$ Las variaciones en el cobro, según implica Daniela Marino, se heredaron de las negociaciones entre caciques y encomenderos durante la primera mitad del siglo XVI. ${ }^{62}$

No obstante las muchas fuentes que constatan las notables diferencias en las cantidades que pagaban los distintos pueblos a lo largo del periodo colonial, la existencia de algún grado de variación en el pago dentro de los pueblos casi no se ha registrado. Aunque varios de los autores mencionados señalan la aplicación de exenciones a diferentes categorías de tributarios, ${ }^{63}$ la modificación por las autoridades de los

59 Miranda, El tributo indígena, p. 152. Sánchez Santiró, Corte de caja, pp. 141-142. Cabe subrayar que la incapacidad de establecer un sistema adecuado de avalúo fue una de las limitantes notorias al momento de intentar cobrar contribuciones directas, que se calculaban a partir de los bienes o ingresos de los individuos, durante el periodo gaditano y después de las independencias americanas.

60 Fonseca y Urrutia, Historia, p. 429; Maniau, Compendio, p. 10; Gibson, The Aztecs, pp. 202-203; Marino, “El afán”, p. 63 et passim.

61 Fonseca y Urrutia, Historia, p. 429.

62 Marino, “El afán”, p. 63.

63 En general, a lo largo del periodo colonial, estaban exentos los caciques 
pueblos de las tasas de los tributos - oficialmente uniformes - según las condiciones económicas de los tributarios sólo aparece en el trabajo de Gibson. ${ }^{64}$ No obstante su prohibición en 1759, a finales del siglo xviII, en lo que posiblemente haya sido otro mecanismo para redistribuir la carga de las contribuciones, algunos pueblos de la Nueva España utilizaban fondos de las cajas de comunidad, provenientes del alquiler de las tierras comunales o de otras fuentes, para pagar el tributo y las obvenciones eclesiásticas. ${ }^{65}$

En la región andina las tasas de cobro durante el periodo de la dominación española se basaron en una valoración inicial de las tierras de cada comunidad ${ }^{66} \mathrm{y}$, como se ha mencionado, había mayor número de distinciones dentro de la categoría de "indio", las que - por lo menos al momento de comenzar las reformas aplicadas entre 1765 y $1790-$ no parecen haber implicado muchas variaciones, más allá de

y sus hijos primogénitos, las mujeres (a veces), los hombres menores de 15 años y mayores de 50 (con algunas variaciones) y las personas con dificultades que limitaran su capacidad de trabajar y, en la Nueva España y el Reino de Guatemala, los indios del cabildo - responsables de la recaudación del tributo - durante el periodo de su gestión. Spores menciona que los mayeques, siervos vinculados a las tierras de los caciques y los nobles también estaban exentos en la Mixteca en el siglo xvi. Spores, The Mixtec, p. 74. Sin embargo, hubo otras exenciones aplicadas, en ciertos lugares y en ciertos momentos, a otras personas, como podían ser indios con otras cargas civiles o religiosas.

${ }^{64}$ Gibson, The Aztecs, pp. 201, 207. En general, los ejemplos que cita Gibson son del siglo xvi, pero menciona el caso de Coyoacán en 1731, donde la cantidad que pagaba cada tributario correspondía a la extensión de tierra que trabajaba. Gibson, The Aztecs, p. 207.

65 TANcK, Pueblos, pp. 47-48, 59.

${ }^{66}$ Klein, “Fiscalidad”, p. 25. Santamaría, "La propiedad”, p. 270 y "Recaudación”, p. 86. 
las divisiones claves de originarios, forasteros y yanaconas, en términos de las tasaciones del tributo. ${ }^{67}$

Después de las reformas de Carlos III, que se discutirán más adelante, sólo tres categorías de tributario se mantuvieron en la zona andina. Los originarios, forasteros con tierra y los yanaconas debieron pagar la tasa entera del tributo, pero los forasteros sin tierra pagaban la mitad o aún menos si no tenían acceso a tierras suficientes. Por otra parte, los yanaconas, que vivían y trabajaban en las haciendas de los españoles, fueron exentos de la mita, como también lo fueron algunos artesanos que podían cumplir con su servicio personal por medio de un pago aparte realizado en dinero o con trabajos especializados. ${ }^{68}$ Dentro de estas tres agrupaciones las tasas no variaban mucho, de manera que la categoría fiscal de indio, dentro de la cual podían estar incluso personas que habían sido categorizadas como mestizos anteriormente, tenía cierta uniformidad, aunque seguramente más matizada que en Nueva España y el reino de Guatemala.

La complejidad de las obligaciones fiscales en los sistemas tributarios prehispánicos, en especial las variaciones en los cobros dentro de los pueblos, se perdió en gran parte durante el siglo Xvi, en particular en la Nueva España, y las reformas en la región andina en la segunda mitad del siglo XVIII simplificaron aún más el sistema en estos territorios.

Desde el último tercio del siglo XVI, el sistema español vinculaba la tasa del tributo con la capacidad económica de cada pueblo como unidad, e ignoraba las variaciones económicas dentro de los pueblos, y en este sentido se

${ }^{67}$ Díaz Rementería se refiere a vagabundos, mostrencos, alcabaleros, zédulos, plateros y chilches. Díaz Rementería, "En torno”, pp. 57-58. ${ }^{68}$ Díaz Rementería, “En torno”, pp. 55-58. 
diferenciaba, en cierto grado, de los sistemas prehispánicos y también de los sistemas vigentes en el reino de Castilla. En el cálculo de las tasas a aplicar para los servicios castellanos y el tributo indiano se consideraba cada pueblo como unidad, según un estimado de sus capacidades económicas, pero mientras en Castilla se clasificaba a los pecheros según su capacidad económica, en América se categorizaba a los tributarios principalmente según su designación socioétnica, edad y estado civil. Al parecer, el sistema tributario en Hispanoamérica reforzaba la idea de una homogeneidad dentro de cada pueblo, que beneficiaba a los sectores indios que tenían mayores ingresos provenientes de la participación en el mercado como productores o comerciantes (a quienes les habría recaído el pago de la alcabala si tuvieran que cumplir con las obligaciones fiscales que correspondían a los españoles), sectores que, como veremos más adelante, no necesariamente querían que se eliminara el tributo.

\section{DEL PORQUÉ EL PECHO NO SE COBRÓ EN AMÉRICA}

Con la conquista y la temprana colonización, la sociedad estamental castellana se mantuvo en América, pero los estamentos heredados del medievo que definían las sociedades europeas de la época (clero, nobleza y tercer estado) perdieron influencia ante el desarrollo de estamentos que se distinguían con base en las adscripciones socioétnicas de clase o calidad ${ }^{69}$ Dividida en un inicio en españoles e indios (con

${ }^{69}$ Solano explica brevemente los factores que incidían en la definición de la "calidad" del individuo. Solano, "La construcción", p. 66. Bien podría argumentarse que las divisiones estamentales en el sur del reino de Castilla también tenían su aspecto "étnico", en la medida en que los 
el reconocimiento de la existencia de nobles y plebeyos dentro de este segundo grupo) y posteriormente complejizada con la agregación de los negros, mestizos, mulatos, zambos y demás clases, la nueva sociedad no abandonaba el uso de las divisiones estamentales, cada una con sus particularidades jurídicas y diferentes obligaciones fiscales.

El proceso del fortalecimiento del Estado español fue el marco en el que se implementaron y desarrollaron los tributos de indios y luego de castas. Este mismo proceso, que buscaba consolidar el poder de la Monarquía ante los demás actores - en la Península, en América y en las posesiones europeas y asiáticas -, subyacía en la posición tenaz que mantuvo el rey ante los intentos de los encomenderos por adquirir poderes territoriales y también limitó la posibilidad de que se establecieran Cortes americanas, no obstante los decretos de 1530 y 1593 que preveían la posibilidad de reunir Cortes en México y Cuzco respectivamente, con representantes de diferentes ciudades americanas. ${ }^{70}$

En las páginas anteriores se ha demostrado que en Castilla, a lo largo del periodo del dominio español en América continental, no existía un derecho real que impactara

nuevos cristianos no tuvieron acceso a la hidalguía aun generaciones después de su conversión.

70 Que la ciudad de Méjico tenga el primer voto y lugar entre las de Nueva España y Que la ciudad del Cusco sea la más principal del Perú, y tenga el primer voto de la Nueva Castilla, Recopilación, lib. 4, tít. 8, leyes 2 y 4, p. 109; Portillo Valdés, "Crisis", p. 123. Ya en el contexto de la crisis de la Monarquía, el Cabildo de Santa Fe en Nueva Granada, en su "Memorial de Agravios", enviado al diputado de la Nueva Granada que iba a participar en el Consejo Supremo, anotó que las leyes del reino requerían una reunión de Cortes antes de aplicar nuevos impuestos y derechos, y preguntó por qué no había representación americana correspondiente. Representación del Cabildo de Santa Fe, pp. 108-109. 
económicamente de manera significativa a los vasallos, como era el caso del tributo de indios y de castas en América. Sin embargo, la distinción social que resultaba de la categorización castellana - fiscal entre otras - de pecheros e hidalgos sí resulta un referente interesante para entender el desarrollo de una clasificación fiscal basada en la calidad del individuo que se utilizó durante los periodos colonial y republicano.

La distinción entre hidalgo y pechero, aunque no se eliminó formalmente en América, perdió mucho de su sentido cuando, en 1499, como mecanismo para promover la participación plebeya en las conquistas americanas, la corona eliminó todo pago de pechos en las Indias y, por lo tanto, dejó de solicitar la formación de padrones que indicaran los estados de los españoles en América. ${ }^{71}$ La diferenciación entre pecheros e hidalgos no viajó a América y el interés de la monarquía en evitar el establecimiento de una clase de nobles americanos que intentara desarrollar señoríos territoriales sirvió para reducir cualquier posibilidad que se erigiera.

La corona sí reconoció la nobleza de los conquistadores, los primeros pobladores y sus descendientes, lo que no incluía a muchos otros españoles que llegaron a las colonias posteriormente. ${ }^{72}$ Así mismo, con tal de asegurar su dominio territorial, la corona prefirió ignorar el hecho de que los españoles en América, en un proceso de autoascenso colectivo, comenzaron a tratarse entre sí como hidalgos, no obstante sus orígenes, en la mayoría de los casos, plebeyos. ${ }^{73}$

${ }_{71}$ Mayagoitia, “Un capítulo”, pp. 509-511; Pérez León, “Hidalgos”, p. 117.

72 Dougnac Rodríguez, Manual, pp. 63-64; Pérez León, "Hidalgos", p. 121.

73 Konetzke, “Formación”, pp. 356-357; Pérez León, “Hidalgos”, pp. 118-126 y “El 'imperativo””, pp. 280-282. 
Como muestra de lo que entonces estaba en juego, en 1567, el Ayuntamiento de la ciudad de México entró en discusiones formales con el virrey Falces sobre el establecimiento de Cortes en la capital novohispana, lo que habría implicado el cobro de los pechos, pero con el entendimiento de que los españoles que ya habitaban en América al momento de establecerlas se consideraran nobles, aunque los que llegaran posteriormente se habrían definido como pecheros, a menos que comprobaran haber tenido un estatus de nobleza en la Península. En cambio, por esta nueva fuente de ingresos reales (la que, repito, habría establecido la distinción entre hidalgos y pecheros), el ayuntamiento exigía la perpetuidad de las encomiendas. ${ }^{74}$ Como la historia posterior ha demostrado, el Ayuntamiento de la Ciudad de México falló en este intento y la resultante ausencia de las categorías de hidalgo y pechero homogeneizó la categoría de español en América, fortaleciendo así las distinciones estamentales construidas sobre la calificación socioétnica del individuo.

\section{CONQUISTADORES Y MILICIANOS: EXENTOS}

El tributo americano se aplicó en un inicio a los indios, ${ }^{75}$ pero a partir de 1574 se formalizó - y no sin dificultades $-{ }^{76} \mathrm{el}$

${ }^{74}$ Mayagoitia, “Un capítulo”, pp. 512-514; Miranda, Las ideas, pp. 138140. Se encuentra la discusión en varias actas del cabildo de la ciudad de México elaboradas entre el 30 de enero y el $1^{\circ}$ de marzo de 1567. Actas de Cabildo, 1871 , lib. $7^{\circ}$, pp. 322-347. Es de notarse que esta negociación se realizó pocos meses después de que se diera por terminado lo que se ha conocido como la Conjuración del Marqués del Valle, que se ideó con el objeto principal de asegurar la perpetuidad de las encomiendas en la Nueva España. Orozco y Berra, Noticia histórica.

75 Castañeda indica que en 1501 hubo un primer intento de aplicar el 
cobro a negros y mulatos libres; ${ }^{77}$ nunca se logró, no obstante algunos esfuerzos, cobrar este derecho a los mestizos. $^{78}$ El tributo se cobraba, entonces, a toda la sociedad americana, con las excepciones de los españoles y los mestizos: la exención de éstos data del principio de la colonia y fue una de las distinciones que los apartaban de los indios y las castas, aunque no es de descartarse que haya influido en esta práctica la idea de que el hijo de un español no debía pagar un derecho que, dentro del pensamiento de los peninsulares recién llegados a América, no sólo recordaba el pecho, y entonces un estatus menor a la hidalguía que los inmigrantes se proponían, sino que también vinculaba al que lo pagaba al estatus de indio y, más adelante, al de negro o casta. Por lo menos en algunos lugares y en algunos momentos, el tributo provocó un rechazo que no se basaba sólo en lo económico sino que también nacía de un menosprecio hacia el estatus social vinculado con la condición de tributario. ${ }^{79}$

tributo indio y resume las primeras directivas en este campo. CASTAÑEDA Delgado, "Un problema”, pp. 494 et passim.

${ }^{76}$ Escobedo Mansilla, "El tributo”; Mörner, La Corona española, pp. $148-49$.

77 Lokken, “Angolans”, n. 65, p. 54; “Que los negros, y negras, mulatos, y mulatas libres paguen tributo al rey”, Recopilación, lib. VII, tít. V, ley primera, p. 320.

78 Richard Konetzke menciona varios intentos para cobrarles tributo a los mestizos en los territorios americanos durante los siglos XVII y xVIII, pero sólo un esfuerzo exitoso en Chile. KonETzke, "Sobre el problema racial”, pp. 196-197. Véase también Menegus Bornemann, “Alcabala”, p. 117 y Mörner, La Corona española, pp. 147-148.

79 Castañeda Delgado, “Un problema”, p. 512; Escobedo Mansilla, "El tributo", n. 6, p. 45; LirA, "El aspecto fiscal”, p. 40; MörNER, La Corona española, p. 149. Para una discusión interesante sobre 
A lo largo del periodo colonial, tal y como se les había ofrecido inicialmente a los pecheros, las exenciones aplicadas a algunos indios, negros y mulatos se relacionaron con sus actividades - en diferentes lugares y en distintos momentos históricos - como fuerza armada: los indios principalmente como aliados en la conquista inicial y los negros y mulatos como miembros de las milicias. La exención de los "indios conquistadores", ${ }^{80}$ como se les ha llamado, fue un reconocimiento por su participación militar en las guerras de conquista y, al tomar en cuenta los matices particulares de los dos casos, se asemejó mucho a la exención al pago del pecho que la corona había otorgado a los plebeyos peninsulares en 1499, que funcionó como un aliciente para su participación en las mismas guerras.

De igual forma, al participar en las milicias - a veces en compañías formadas sólo por personas de herencia africana y en otros momentos en compañías integradas con españoles- muchos negros y mulatos libres aplicaron presión y negociaron con éxito una exención al pago del tribu-

la "'naturaleza tributaria del indio"” al comienzo del siglo xix y la relación entre los estatus en América y en la Península, véase Совá NoH, El "indio ciudadano", pp. 70-79 y Granados, "Huérfanos", pp. 313-318.

${ }^{80}$ En esta categoría caben la exención inicial del tributo en todo el territorio tlaxcalteca y las exenciones otorgadas a los descendientes de los tlaxcaltecas y otros pueblos americanos que acompañaron a los españoles durante las conquistas y se trasladaron a las regiones conquistadas. Sobre las exenciones en la Nueva España, véase Sánchez Santiró, Corte de caja, p. 143. Los caciques de Totonicapán, en Los Altos de Guatemala, que heredaron los privilegios de los "indios conquistadores", pero que eran más una especie de clan que una nobleza (había unos 578 a finales del siglo XVIII), actuaron como apoyo a las milicias durante el periodo colonial y tuvieron responsabilidades militares aun en el periodo republicano. Pollack, Levantamiento, pp. 38-40. 
to. ${ }^{81}$ Otros negros y mulatos libres, por lo menos en el caso novohispano dieciochesco, lograron aprovechar el interés de los hacendados locales por asegurarse una fuerza de trabajo cercana, y el deseo de las autoridades virreinales de mantener una presencia armada en ciertas regiones, para extender la exención a todos los de su clase en algunos pueblos. ${ }^{82}$ Con las presiones impuestas por las reformas del último tercio del siglo xviII, sin embargo, los negros y mulatos libres encontraron más dificultades en afianzar su exención del pago del tributo. ${ }^{83}$

Aunque la exención del tributo como premio por la participación en actividades militares no puede entenderse como un ascenso social hacia la nobleza, es de subrayarse que lo que ocurría en América se asemejaba, en términos

81 García Peláez, Memorias, pp. 32-37; Escobedo Mansilla, “El tributo”; Vinson, “Los milicianos”, pp. 54-60; Sánchez Santiró, Corte de caja, p. 143. Al parecer, los ingresos provenientes del tributo de mulatos y negros libres se mantuvieron en niveles bastante bajos y para 1770 se había dejado de cobrar este derecho en el virreinato del Perú a la vez que en la Nueva España se aplicaba poco. DíAz Rementería, “El régimen”, p. 427; TePaske y Hernández Palomo, La Real Hacienda, núm. 677781. Los datos recopilados por Terán demuestran que en la Nueva España se mantuvo el cobro del tributo de las castas hasta el final del periodo colonial. Terán, Tributos. Díaz Rementería nota que cuando, como parte de las reformas en los mecanismos del cobro del tributo que se realizaron en las décadas de 1770 y 1780, se propuso cobrar tributo a los cholos, el virrey de Buenos Aires advirtió de los riesgos que este cobro habría podido significar ante un eventual levantamiento indígena. Díaz RementeRÍA, “En torno”, p. 59.

82 Vinson, “Los milicianos”, pp. 54-60. Se temía la movilidad de la población negra y mulata libre hacia otros pueblos o distritos donde se aplicaba la exención.

${ }^{83}$ Vinson, “Los milicianos”, pp. 58-59; CAstañeda García, “Hacia una sociología fiscal”, pp. 166-170. 
fiscales y sociales, al proceso por el cual los caballeros castellanos que participaron en la reconquista lograron exenciones fiscales y muchas veces la hidalguía. ${ }^{84}$ En los dos casos, la exención fiscal autorizada como premio por el uso de las armas demostraba, por un lado, la vigencia de una herencia medieval que relacionaba la nobleza con la función militar y, por otro, el aprovechamiento de esta herencia por parte de los plebeyos que habían participado en las guerras de reconquista y conquista - o bien como fuerza armada en la defensa de los dominios españoles ante amenazas exteriores o rebeliones en su interior.

\section{EL TRIBUTO EN EL “PACTO COLONIAL”}

Como se ha mencionado, el tributo indígena se aplicó, con las modificaciones que se han mencionado, a partir de los mismos mecanismos que habían funcionado en los diferentes territorios americanos antes de la conquista, lo que reflejaba la política comúnmente practicada en los diversos y extensos espacios europeos donde la monarquía española reinaba en el siglo xvi. Según las disposiciones iniciales del rey, el tributo español debía ser menor al que cobraban los señores naturales, de manera que los indios se acercaran más fácilmente al cristianismo y al nuevo sistema de gobierno, pero en la práctica se sabe de las muchas vejaciones y maltrato que el pago del tributo y la provisión de los servicios personales provocaron entre las poblaciones americanas, en especial antes de la aplicación de las Leyes Nuevas en 1542.

${ }^{84}$ Pérez León, “Hidalgos”, pp. 51-54. 
Se ha argumentado que bajo el sistema de gobierno incaico, un pacto entre los gobernantes y los campesinos aseguraba el acceso a la tierra a cambio del pago del tributo; este quid pro quo se habría mantenido bajo los regímenes españoles y habría sido la justificación, por lo menos desde la perspectiva de la población andina, del tributo colonial. Este pacto se habría basado en el supuesto de que los incas, como afirmó el virrey Abascal en su Memoria escrita durante la época de las independencias, habían sido los propietarios de la tierra. ${ }^{85} \mathrm{La}$ idea del pacto entre los gobernantes (incas, españoles y gobiernos republicanos) y los indígenas ha cobrado mucha fuerza en el mundo académico a partir de los trabajos de Tristan Platt en torno a los indígenas en la parte norte del departamento boliviano de Potosí que resistieron la eliminación del tributo a finales del siglo xIx; el planteamiento se ha fortalecido mediante reconstrucciones históricas de varios casos en los cuales distintas comunidades andinas mostraron renuencia ante la eliminación de las contribuciones en diferentes momentos durante el siglo XIX. ${ }^{86} \mathrm{~A}$ raíz de investigaciones en el ámbito regional,

85 Sánchez Albornoz, Indios, n. 23, p. 205.

${ }^{86}$ Platt, Estado. Se ha retomado la suposición de la existencia de este "pacto" entre el Estado y las comunidades en el periodo colonial por varios autores en referencia a la aplicación de las diferentes contribuciones que sustituyeron al tributo indio en los países andinos después de las independencias. Contreras, "Estado republicano", y "El impuesto"; Palomeque, “Estado", p. 400; Peralta Ruiz, "Fiscalidad”, En pos, y "Comunidades"; Morelli, Territorio, pp. 159-182; IrurozQui, "Las paradojas”, y "Sobre el tributo"; Soux, "Tributo". Recientemente, Irurozqui ha argumentado que después de la independencia boliviana, los indígenas compartían la visión de los legisladores nacionales al considerar que el pago de la contribución era la manera en que participaban en, 
la existencia del acuerdo resulta menos uniforme, de manera que aparece en ciertos lugares y circunstancias, pero no en todas. ${ }^{87}$

Existen dos posiciones, sin embargo, sobre las condiciones necesarias para el mantenimiento del "pacto" colonial, el que yo entiendo como los presupuestos básicos que formaban el trasfondo de la hegemonía (en el sentido gramsciano de la palabra) y de la economía moral que existieron a lo largo del periodo colonial. Mientras todos los investigadores que participan en el debate concuerdan en que los indios cumplían con las condiciones del pacto al pagar el tributo, hay discrepancia en torno a las responsabilidades de la monarquía en él: algunos consideran que ésta debía asegurar la impartición de la justicia - y la defensa de los intereses de los indios,$-{ }^{88}$ mientras otros argumentan, de acuerdo con el vulgo andino, que el rey debía asegurar el acceso a la tierra comunal. Así que Owensby plantea: "[h]e aquí los términos de un pacto político entre un rey tributario y vasallos indios - el derecho y el tributo como obligaciones recíprocas de la justicia”, ${ }^{89}$ En cambio, Menegus sostiene que "[e]n otras palabras, el pacto se traduce de la siguiente manera: los indios le tributan en reconocimiento a la soberanía del monarca, y él, al reconocerlos como sus vasallos, les

y formaban parte de, la nueva república nacional boliviana. IRURozQUi, "Las paradojas" y "Sobre el tributo".

${ }^{87}$ Langer, "Bringing"; O’Phelan, "Presentación”, p. 422.

${ }^{88}$ Menegus Bornemann, "Alcabala”, p. 110; Owensby ha desarrollado esta idea de manera extensa. Owensby, "Pacto" y Empire.

${ }^{89}$ Owensby, "Pacto", pp. 82-83; véase también Díaz Rementería, "El régimen”, 410. 
reconoce su derecho a la propiedad". ${ }^{90} \mathrm{El}$ acuerdo general de que los indios pagaban el tributo para satisfacer su parte del pacto resulta iluminador para subrayar su importancia en el periodo colonial, mientras que las diferentes posiciones sobre el papel del rey en el mantenimiento de la hegemonía ofrecen insumos importantes para entender cómo se pudiera justificar la aplicación de los impuestos de capitación cuando los nuevos gobiernos independientes los asumieron después de las independencias.

\section{EN LA BÚSQUEDA DE MAYORES INGRESOS:}

EL TRIBUTO EN EL SIGLO DE LAS LUCES

A lo largo del siglo xviII, la Monarquía española implementó una serie de reformas, fiscales entre otras, en la Península y en las colonias de ultramar, que apuntaban al desarrollo de una mejor posición de la corona en la rivalidad interimperial que sostenían Gran Bretaña, Francia y España. Entre los muchos cambios propuestos e impuestos, la corona promovió dos que son de particular importancia para los fines de esta investigación: el intento fallido de aplicar una "única contribución" que habría fijado un impuesto sobre la propiedad y reemplazado las rentas provinciales mencionadas anteriormente, $\mathrm{y}$ las modificaciones en la recolección del tributo que se implementaron en América a partir de 1769 y, con más vigor, con el establecimiento del sistema de intendencias. Más adelante se hará referencia al primero por su relevancia como antecedente del impuesto directo aprobado por las Cortes de Cádiz en 1813 y de las contribuciones

90 Menegus Bornemann, “Títulos”, p. 149. 
similares aplicadas por los nuevos estados nación después de las independencias.

\section{Las reformas}

Las reformas en el sistema de recolección del tributo trataron, como muchas de las modificaciones aplicadas por la Monarquía española a su sistema fiscal a lo largo del siglo XviII, de sistematizar sus mecanismos de recaudación para aumentar sus ingresos y, en muchos casos, como señala Marino, de aplicar leyes y decretos vigentes pero ignorados o poco respetados. ${ }^{91}$ Entre otras acciones, las reformas iniciales en torno al tributo - aplicadas en la Nueva España a partir de 1769 (con Gálvez), en la Audiencia de Quito en 1778 y en los virreinatos de Perú y Río de la Plata en 1779- previeron la realización de nuevas matrículas cada cinco años en lugar de mantener vigentes las mismas (a veces por varias décadas), ${ }^{92}$ el fortalecimiento de un sistema de fianzas mediante terceros que asegurara la entrega del tributo recaudado por los alcaldes mayores y corregidores (y después subdelegados), la reducción del número de categorías de personas exentas del tributo y la centralización de la responsabilidad por el cobro. ${ }^{93}$ De manera particular, en

${ }^{91}$ Marino, "El afán”, p. 64.

92 Wortman, Government, p. 140; Sala i Vila, $Y$ se armó, pp. 34-35.

93 Díaz Rementería, "El régimen"; Cahill, From Rebellion, pp. 153168; Morelli, Territorio, pp. 161-165. Sobre la reducción en las categorías de los exentos, véase Cahill, "Curas", p. 252; Mazín Gómez, Cabildo, p. 356; Morelli, Territorio, p. 162. En Filipinas se había aplicado con éxito una reforma al sistema de cobro de tributos en la década de 1740 que incluyó dos prácticas que se implementarían en América (y de nuevo en Filipinas) décadas después: la reducción en el número 
la Audiencia de Quito y el virreinato del Perú la reducción en el número de categorías exentas de los cobros, y la consecuente pérdida del estatus de exento, como señala Cahill para el caso de la región sur de los andes peruanos, tuvo sus implicaciones, sociales además de fiscales, para la estructuración de la sociedad andina en general y de los ayllus en particular. ${ }^{94}$

Las reformas a los sistemas de recaudación del tributo antecedieron por pocos años a la implementación de las ordenanzas de intendentes que durante la década de los ochenta modificaron la administración territorial y, particularmente, la fiscal en toda la América hispana. ${ }^{95}$ Con el sistema de intendencias, se refrendaron muchas de las reformas establecidas (varias de ellas ya refrendadas de por sí) en la década anterior en torno al tributo y se comenzó a pagar a las autoridades responsables por la recaudación un porcentaje del total entregado a los reales erarios. Las ordenanzas de la Nueva España y las de Buenos Aires definieron de manera uniforme que $1 \%$ del total recaudado se quedaría con los gobernadores y alcaldes de indios - los responsables en el trato directo con los tributarios-, pero en las ordenanzas de la Nueva España se asignaba 5\% del total

de personas exentas del tributo y un recuento de los tributarios. Alonso Álvarez, “¿Qué nos queréis?”, pp. 35-41.

94 Cahill, From Rebellion, p. 155.

95 Daniela Marino nota que la época de la reforma en la Nueva España incluyó no sólo las reformas de Gálvez y la aplicación de la Real Ordenanza de intendentes, sino también la Ordenanza de Revillagigedo en 1794 y que siguieron los intentos por reformar el sistema de tributos hasta la crisis de la Monarquía. Marino, "El afán”. 
recaudado a los subdelegados mientras en las de Buenos Aires les correspondía sólo 3 por ciento. ${ }^{96}$

La reglamentación y la aplicación de las ordenanzas, tal vez aún más en el recién creado virreinato del Río de la $\mathrm{Pla}$ ta y en el de Perú, respondían en cierta manera a las problemáticas y las realidades sociales que habían dado cauce a la Gran Rebelión (1780-1781). En respuesta al papel importante que tuvieron los caciques en los diferentes conflictos englobados en los levantamientos andinos, las ordenanzas hicieron a un lado a los señores naturales en la recaudación del tributo, y aunque buen número de los nuevos "recaudadores" o "cobradores" prefirieron llamarse "caciques recaudadores", en muchos casos ya no eran "señores naturales" sino otros indios, mestizos o españoles cuya actividad principal en torno al gobierno de los diferentes ayllus era la recolección del tributo. ${ }^{97}$ En la Audiencia de Quito, las reformas de estos años modificaron el papel del gobernador indio para que fungiera como auxiliar de los subdelegados y también cambiaron la forma de seleccionarlo, de manera que la Audiencia lo elegía de una terna propuesta

96 Real Ordenanza, art. 132, pp. 155-156; CAhill, “Curas”, p. 247. En la Nueva España, se indicó que el 1\% otorgado a las autoridades indias eliminaba la necesidad de que los gobernadores y alcaldes recibieran algún pago de las cajas de comunidad. TAnck, Pueblos, pp. 23, 29.

97 Cahill, From Rebellion, pp. 153-168. Una cédula de 1783 instruyó a los oficiales peruanos a que dieran preferencia a los españoles sobre los indios como caciques y recaudadores. CAHILl, From Rebellion, p. 160. Ocurrió un antecedente interesante cuando en 1767, después de la rebelión en el actual territorio de Michoacán, Gálvez castigó a los pueblos con la pérdida de sus autoridades por un periodo de 25 años: en lugar de gobernadores, los "comisarios de tributo" se ocupaban de la recaudación. Terán, "Liderazgo", pp. 371-72. 
por el administrador de tributos, en vez de ser seleccionado por la comunidad, como había ocurrido anteriormente. ${ }^{98}$ En el caso novohispano, las reformas no impactaron tanto a los señores naturales que, como se ha argumentado, tuvieron un papel menor que en la región andina, pero hizo más difícil que los gobernadores se reeligieran. ${ }^{99}$

Las reformas en los mecanismos de recolección del tributo, igual que muchas de las reformas hacendísticas que acompañaron a la instalación de las intendencias, lograron aumentar de manera notable los ingresos de su ramo, lo que no debe sorprender pues se ha considerado que el sistema de intendencias fue, principalmente, un paso desde una manera de gobernar enfocada en la justicia hacia otra que buscaba el crecimiento económico y, como corolario a éste, aunque también importante por sí mismo, mayores ingresos fiscales. En la Nueva España y en el reino de Guatemala, donde se

${ }_{98}$ Morelli, Territorio, p. 164. Existió la propuesta de que los curas se volvieran auxiliares de la administración tributaria y que su salario dependiera del número de tributarios en sus parroquias, para así promover que se hicieran los censos sin ocultaciones. Morelli considera que también se buscaba que el párroco se transformara "en un auténtico defensor de la comunidad, que se esmerara en frenar los procesos de emigración y concertaje". MoRelli, Territorio, n. 11, p. 163. Si la interpretación de Morelli es correcta, prevé la actitud del gobierno republicano del Perú durante la primera parte del siglo xIX, que buscaba fortalecer las comunidades y así asegurar un alto número de tributarios y entonces un mejor ingreso proveniente de la contribución directa. Además, corresponde a lo argumentado por Martínez Peláez sobre el interés predominante de la corona y de las autoridades españolas en el reino de Guatemala de priorizar el cobro del tributo de indios sobre su participación eventual en los repartimientos de trabajo. Martínez Peláez, Motines, pp. 77-78.

99 Escobar Ohmstede, “Del gobierno”, p. 8. 
aplicaron las ordenanzas novohispanas, ${ }^{100}$ las reformas consideraban una nivelación en la tasación del tributo a 16 reales para los indios y 24 para las castas. ${ }^{101}$ En la Nueva España este cambio fue suspendido por la Junta Superior de Real Hacienda ${ }^{102}$ y en Guatemala la nivelación se aplicó a partir de 1802 (aunque de manera inconsistente), años después de la aprobación de las ordenanzas; allí provocó una pequeña revuelta en la alcaldía mayor de Verapaz, al significar la nivelación casi una duplicación de la tasa del tributo. ${ }^{103}$

No obstante las muchas inconsistencias en su aplicación, las nuevas políticas sobre el tributo rindieron frutos con grandes aumentos en la Audiencia de Quito, y en el virreinato de Perú el rubro de los tributos se convirtió, gracias a la reducción en los ingresos mineros, en el más importante de los ingresos reales entre la década de 1780 y el final del periodo colonial. ${ }^{104}$ En el caso novohispano, el nuevo sistema acompañó a un aumento en la cantidad recaudada, pero existen discrepancias en torno a la relativa importancia que las reformas - aplicadas de modo parcial- tuvieron en

100 En el reino de Guatemala inicialmente se aplicaron las ordenanzas de Buenos Aires hasta que se publicaran las de la Nueva España. SAmayoa Guevara, El régimen de intendencias.

101 Según Fonseca y Urrutia, en 1753, el contador José Rodríguez Gallardo propuso a la real audiencia de México que el tributo para todos los indios fuera de 16 reales y medio - además de lo cobrado en razón de "ministros" y "hospitales" -. Fonseca y Urrutia, Historia, p. 430.

102 Pietschmann, Las reformas, p. 217; Marino, "El afán”, p. 73, n. 22; García Pérez, "El régimen tributario”, p. 283.

103 Fernández Molina, Los tributos, pp. 22-30; Gutiérrez Álvarez, "Racismo".

104 Sobre la Audiencia de Quito, véase Morelli, Territorio, p. 164 y sobre Perú, Díaz Rementería, "El régimen”, pp. 428-429; Klein, "Fiscalidad”, pp. 27-29; SAla i Vila, Y se armó, pp. 281-285. 
promover este aumento. Recientemente, Gutiérrez Núñez ha comprobado lo que Marino señaló como posibilidad hace dos décadas: el nuevo sistema controló mejor la matriculación en la Nueva España (como hemos visto que ocurrió en Filipinas unas décadas antes), o por lo menos en la intendencia de Valladolid, donde el aumento en los vagos y laboríos matriculados provocó una resistencia por parte de los hacendados y rancheros en quienes recaía la responsabilidad del cobro. Lo anterior contrasta con lo que Herbert Klein ha afirmado cuando indicó que el incremento en el tributo se debía simplemente a un aumento poblacional. ${ }^{105}$

No obstante las preocupaciones manifiestas de los reformadores sobre el cobro del tributo en el reino de Guatemala desde 1763, las reformas no causaron aumentos en las sumas recaudadas en este ramo, e incluso hubo una tendencia hacia su reducción entre la década de 1760 y el principio del siglo XIX. ${ }^{106}$

Elpensamiento de los reformadores en torno a la eliminación del tributo

En el último cuarto del siglo xviII, varios pensadores y oficiales en Hispanoamérica abogaron por la eliminación del tributo con argumentos que tendían a basarse en la demostración

105 Marino, “El afán”, pp. 77-79. Gutiérrez Núñez, “La Real Hacienda”, pp. 37-41. Silva Riquer considera que una de las razones del aumento fue el incremento en la remuneración del trabajo de los indios en dinero durante el siglo xviII. SiLva RiQuer, "El trabajo", p. 29.

106 Wortman, Government, pp. 140-141, tabla 7.2, p. 146 y tabla 7.5, p. 153. En su discusión sobre Chiapas, sin referirse a los montos recaudados, Wasserstrom indica un aumento de 5070 tributarios indígenas en 1761 a 9372 en 1816-1817. Wasserstrom, Clase y sociedad, p. 92. 
de los beneficios que ésta habría comportado para los erarios reales, aunque a menudo también se vinculaban con propuestas para reducir o eliminar las distinciones entre los estamentos. Algunos neogranadinos propusieron la eliminación del tributo indio como elemento de un argumento más amplio que fomentaba la españolización del indio, ${ }^{107}$ retomando la propuesta que hiciera Campillo y Cosío décadas atrás de que se repartieran las tierras comunales de los indios y que éstos pagaran los mismos impuestos que correspondían a las demás clases. Los reformadores americanos y peninsulares promovían la eliminación del tributo y de los servicios personales, entre otras políticas, como mecanismos que impulsaran la mejor inserción del indio en el mercado: al tener éste un terreno propio, y la certeza de que sus ganancias no habrían de terminar en manos de otros, tendría la motivación económica para trabajar más, producir más y pagar otros impuestos, como la alcabala, que subsanarían lo perdido por la abolición del tributo.

En la misma línea, en 1790, el intendente de la provincia de México propuso que se eximiera del tributo a aquellos indios que se vistieran como españoles. ${ }^{108}$ Pocos años después, en 1799, el obispo de Michoacán y su cabildo catedral enviaron un documento al rey, elaborado por el futuro obispo Abad y Queipo, en el que proponían varios mecanismos para ayudar a mantener sumisa a la población y simultáneamente aumentar los ingresos reales: la eliminación del tributo, la redistribución de la tierra y el acceso de las castas a los

107 Mayorga García, “La extinción”, pp. 53-56.

108 Pietschmann, “Revolución”, p. 29. 
empleos civiles “que no requieren nobleza", entre otros. ${ }^{109}$ En 1803, la Junta Real de Hacienda de la Nueva España decidió promover la eliminación del tributo personal, con el fin de equiparar a los diferentes estamentos y entonces permitir el pago de la alcabala por los indios, puesto que se había calculado que su exención perjudicaba al erario. ${ }^{110}$

Las reformas aplicadas en el último tercio del siglo XVIII aumentaron los ingresos reales en muchas regiones y, en ciertos contextos, reestructuraron las relaciones dentro de las comunidades y los vínculos entre éstas y las autoridades españolas. Asimismo, la reforma propuesta que habría implicado la eliminación del tributo se discutía en muchos ambientes en las décadas antes de la crisis de la monarquía y ésta, como comúnmente ocurre con las crisis, permitió muchos cambios, entre ellos la abolición del tributo de indios y de castas.

\section{LA ELIMINACIÓN DEL TRIBUTO}

Entre 1808 y 1825 los territorios de la Hispanoamérica continental pasaron de ser colonias - como las conceptualizaban

109 Jaramillo Magaña, Hacia una Iglesia, pp. 158-161; Representación sobre la inmunidad. En 1809, Abad y Queipo sugirió que, con el fin de fortalecer el ejército español en la Nueva España, se reclutara soldados de las clases tributarias ofreciéndoles la eliminación del pago del tributo mientras participaran en el ejército y, para los que sirvieran bien, la exención permanente. Representación sobre la necesidad de aumentar. El mismo Abad indicó en un documento elaborado en 1810 que él había recomendado la eliminación del tributo desde 1791. Representación a la regencia.

110 Menegus Bornemann, “Alcabala”, p. 122. Menegus ha demostrado los problemas que las autoridades fiscales tenían para identificar el estamento de los comerciantes, lo que les dificultaba realizar los cobros correctamente y, entonces, hacía sufrir a los erarios reales. MEnegus Bornemann, “Alcabala”, pp. 116-123. 
los reformadores borbones - a ser estados independientes; contemporáneamente, dejaron de pertenecer a una monarquía con pretensiones centralistas y absolutistas para establecerse en regímenes que buscaban regirse por principios asociados con el republicanismo y el liberalismo político y económico. Al final de estos largos años - densamente llenos de un amplio abanico de propuestas y proclamaciones políticas, guerras, constituciones y rebeliones - el tributo de indios y de castas se había eliminado como tal, aunque los procesos que llevaron a este resultado común variaban mucho en los diferentes territorios americanos.

La crisis de la monarquía dio pauta para el comienzo de una serie de dinámicas relacionadas con el tributo, algunas de las cuales se venían operando y otras que la misma coyuntura propició. Existía el grupo de pensadores ya mencionado que promovía la eliminación del tributo con el fin de mejorar los ingresos al erario real, y a la vez había quienes creían en la importancia de la igualdad ante la ley y, entonces, en la necesidad de eliminar los diferentes privilegios y obligaciones correspondientes a los diversos grupos corporativos y estamentales.

Mientras estas ideas formaban parte del contexto ideológico en el que la crisis de la monarquía se desenvolvió, durante la vacatio regis se crearon condiciones particulares que fomentaron la eliminación del tributo. En primer lugar, la presencia de los conflictos armados hizo necesario que los diferentes gobiernos y sus opositores se acercaran a los sectores populares para asegurar su apoyo, siempre con la intención de evitar que las políticas adoptadas perjudicaran su propio sustento económico. ${ }^{111}$ En segundo lugar, en

111 Para una discusión sobre el cobro de los impuestos en el contexto de 
la medida en que la eliminación del tributo podía implicar también la abolición de las comunidades corporativas y la distribución de la propiedad que poseían - como fue el caso en algunas regiones de la Nueva Granada y Chile-, habría permitido que algunos individuos aprovecharan la situación para ganar acceso a las tierras comunales. ${ }^{112}$ En casi todos los casos resulta necesario evaluar las decisiones que los realistas, independentistas y autonomistas tomaron para eliminar el tributo con atención a cuatro factores: las ideas sobre igualdad y sobre el fomento económico, la necesidad de acercar a potenciales aliados que estaban sujetos al pago del tributo, las necesidades fiscales coyunturales y el acceso a las tierras comunales de los pueblos de indios.

Por otra parte, los indios y las castas que pagaban el tributo no necesariamente habrían tenido una posición única en torno a su potencial eliminación. Si la eliminación del tributo hubiera implicado pagar otros cobros como la alcabala o los impuestos eclesiásticos, algunos indios habrían podido verse perjudicados por el cambio, en particular aquellos que se dedicaban al comercio o a la producción de bienes. ${ }^{113}$

las guerras y rebeliones relacionadas con las luchas independentistas en Perú, Nueva España y el Alto Perú, respectivamente, véase SAla I Vila, Y se armó, pp. 238-39; Serrano Ortega, "El sistema fiscal” y Soux, "Tributo".

112 En la región central de la Nueva Granada, las autoridades españolas habían facilitado que los blancos y mestizos tuvieran acceso a las tierras comunales desde mediados del siglo XVIII ante un fuerte aumento en la población de estos grupos y muchas presiones sobre los resguardos indios. Meisel, Crecimiento, pp. 33-35.

113 Entre 1770 y 1784, las reformas impuestas bajo Carlos III permitían que los "cholos" (entendidos como hijos de mestizo e indio) fueran matriculados como tributarios en Perú, y algunos mestizos, argumenta Sala i Vila, prefirieron integrarse a las comunidades indias peruanas 
Por otro lado, si se sigue una lógica estrictamente económica, los indios y las castas que se dedicaban exclusiva o principalmente a la producción para el autoconsumo habrían preferido eliminar el tributo en vista de que no se les habría aplicado la alcabala.

En octubre de 1809, Miguel de Ezyaguirre, el protector de indios de Perú, propuso la eliminación del tributo en el documento "Ideas acerca de la situación del indio", que se elaboró en parte sobre la base de las quejas que los indios habían hecho llegar a los protectores provincianos en torno al tributo y otros asuntos. Además de presentarlo ante el gobierno virreinal y enviarlo a las autoridades peninsulares, Eyzaguirre circuló el escrito entre algunos de los pueblos peruanos. ${ }^{114}$ Según el virrey Abascal, con este escrito Eyzaguirre influyó en la decisión tomada por el Consejo de Regencia, en mayo de 1810, de eliminar el tributo, además de promover una resistencia india al pago del mismo desde mediados de 1809 en algunos pueblos de Cajatumba. ${ }^{115}$ Eyzaguirre y su propuesta también se advertían como causas de las dificultades en el cobro del tributo

y pagar el tributo. Díaz Rementería, “Régimen”, pp. 427-428; Sala I VILA, $Y$ se armó, pp. 51-52. En el periodo gaditano, al parecer, los indios de San Salvador y León preferían continuar con el pago del tributo y del sustento que entregaban a los curas en lugar de pagar la alcabala y los derechos parroquiales. Fernández Molina, Los tributos, p. 35.

114 Chassin, “Protecteur”, n. 29, p. 74. Eyzaguirre sustentaba su argumentación en lo abusivo que era el sistema de tributos, en la igualdad de los indios ante la ley según lo pronunciado por el Consejo de Regencia y en la lógica de que los indios aportarían más a la economía y al fisco si se les repartieran tierras y pagaran los impuestos que correspondían a todos los demás grupos sociales (una idea que, como se ha mencionado, era bastante difundida en esta época). Chassin, "Protecteur”, pp. 65-66.

115 Chassin, "Protecteur”, pp. 70 y 74, n. 29. 
que los subdelegados de Putinza e Ica preveían a principios de 1810, e incluso de la creencia entre los indios de Ica de que "de un instante a otro, p[odía]n hallarse libres de esta contribución". ${ }^{116}$

A finales de diciembre de 1809, en la ciudad de Valladolid (actualmente Morelia), un grupo de los criollos más poderosos de la ciudad, con el apoyo probado de los indios de los barrios de ésta, empezaron a organizar una conjura o una conspiración con los objetivos de someter al gobierno de la intendencia de Valladolid y "establecer una junta soberana en las provincias que componían el muy antiguo obispado de Michoacán”. ${ }^{117}$ En consonancia con las opiniones de pensadores como Abad y Queipo y buena parte del grupo dominante en Valladolid, los criollos rebeldes propusieron la eliminación del tributo y de las cajas de comunidad, con la idea de que estas propuestas facilitarían el apoyo de los indios, cuya participación los conjurados consideraban necesaria en un eventual cabildo abierto y también como un referente - a favor de la conspiración pero poco violentoque las castas y la plebe urbana seguiría en un eventual conflicto abierto con las autoridades. ${ }^{118}$

116 Glave, "Cultura política”, p. 403. Desde principios de 1810 una rebelión indígena en el Alto Perú mantenía como una de sus propuestas el no pagar el tributo hasta que se definiera a quién se le debía pagar. Soux, “Tributo", pp. 25-26. Véase Glave, "Cultura política”, para más discusión de este movimiento y de otros en el mismo periodo en Perú y el Alto Perú. Sala i Vila menciona, como resultado de las influencias de la Junta Tuitiva en La Paz, dificultades en recaudar el tributo en el partido de Chucuito en el Puno ya en 1809. Sala i Vila, $Y$ se armó, p. 163.

117 TERÁN, “1809”, p. 34.

118 Terán, “1809” y “El movimiento”. 
Que fuera a causa del escrito de Eyzaguirre, del levantamiento en Caracas de abril de 1810, o por otras razones, el Consejo de Regencia eliminó el tributo que pagaban los indios en la Nueva España - sólo los indios y únicamente en la Nueva España - el 26 de mayo de $1810 .{ }^{119}$ El Consejo también ordenó la repartición de tierras y aguas a los pueblos que los necesitaran, ${ }^{120}$ en consonancia con las ideas económicas, ya mencionadas, posteriormente conocidas como "liberales", que circulaban en España desde mediados del siglo xviII. No obstante la existencia de ideas de tinte liberal que le habrían dado sustento al decreto, en este caso el Consejo actuó principalmente para asegurar el apoyo de los indios ante un posible levantamiento contra la corona, pues el mismo decreto se refiere a la "inalterable lealtad y patriotismo" de los indios, mas ignora completamente la posibilidad de igualar su condición. ${ }^{121}$ En posteriores discusiones realizadas dentro de las Cortes gaditanas, el decreto del Consejo por el cual se eliminó el tributo se discutió en contraposición a otro en el que se autorizó al gobernador y capitán general de Puerto Rico un uso amplio de sus facultades para asegurar la seguridad pública: es decir, los dos decretos se entendieron como mecanismos para asegurar, grosso modo, la tranquilidad social. ${ }^{122}$ En este caso, el

119 Edmundo Heredia argumentó que la disposición del Consejo de Regencia se dio en respuesta al levantamiento de Caracas del 19 de abril de 1810. Heredia, "Los tributos indígenas", p. 60. Granados ha elaborado una discusión dirigida a entender por qué la Regencia decidió eliminar el tributo de indios en la Nueva España. Granados, "Huérfanos", pp. 294-298. 120 Real orden de 26 de Mayo.

121 Real orden de 26 de Mayo.

122 Diario de las discusiones y actas de las Cortes, t. III, sesión del día 15 de febrero de 1811, Cádiz, Imprenta Real, 1811, 21 t. 
Consejo compartía lo expuesto por el obispo Abad y Queipo en un documento enviado a este cuerpo el 30 de mayo del mismo año (casi la misma fecha en que se publicó el decreto por el que se eliminó el tributo), con varias sugerencias dirigidas a reducir las tensiones sociales que ya se advertían en la Nueva España; entre ellas, la propuesta de abolir el tributo de los indios y de las castas se colocó en el primer lugar de la lista. ${ }^{123}$

Pocos meses después, en septiembre de 1810, es de suponerse que el insurgente padre Hidalgo haya proclamado la eliminación del tributo de castas (si no necesariamente el de indios) al alzarse en armas el día $16,{ }^{124}$ lo que refrendó el 19 de octubre del mismo año. Hidalgo y sus tropas se

${ }^{123}$ Como se mencionó anteriormente, Abad y Queipo había solicitado la eliminación del tributo para promover la paz social. Representación a la regencia. José Antonio Serrano ha señalado que el intendente de Guanajuato, Juan Antonio de Riaño, compartía la posición de Abad y Queipo sobre la utilidad de la eliminación del tributo y el cobro de la alcabala a todas las clases por igual. Serrano, "El sistema fiscal", p. 78; Plan de Juan Antonio de Riaño.

${ }^{124}$ Pocos días después del levantamiento de Hidalgo, el 21 de septiembre, un crítico del movimiento insurgente indicó que el líder rebelde había logrado conseguir apoyo "bajo la engañosa apariencia de libertad americana, de tributos, alcabalas, y de todo gravamen”. Don José Simeón de Uría. Véase también Copia de la declaración rendida. Granados nota que en sus primeros decretos, los insurgentes abolieron el tributo de castas y solamente en diciembre de 1810 eliminaron el de indios. Granados, "Huérfanos", pp. 300-301. Sobre esta cuestión, véase también la discusión de Terán. TERán, “¡Muera el mal gobierno!”, pp. 404-405. El texto del decreto de Hidalgo del 19 de octubre se lee: "[...] quede totalmente abolida para siempre la paga de tributos para todo género de castas, sean las que fueren, para que ningún juez ni recaudador exija esta pensión ni los miserables que antes la satisfacían, la paguen [...]”. Bando de don José María Ansorena. 
acercaban a la ciudad de Guanajuato cuando, el 26 de septiembre, el intendente Riaño publicó el bando de la Regencia del 26 de mayo y eliminó el pago de tributo en esa intendencia; resultó un intento sumamente malogrado de afianzar el apoyo de la plebe guanajuatense a la causa realista, pues dos días más tarde los insurgentes tomaron la alhóndiga. ${ }^{125}$

El 5 de octubre de 1810, unas tres semanas después del levantamiento de Hidalgo, el recién llegado virrey de Nueva España, Venegas, publicó el decreto del Consejo de Regencia del 26 de mayo y extendió la eliminación del tributo "y demás gracias concedidas" a las "castas de mulatos, negros y demás de todas aquellas poblaciones que en las presentes circunstancias mant[uviera]n la fidelidad y justa adhesión a la sagrada causa de la patria, y concurr[ier]an a reprimir y sofocar la sublevación que han excitado en San Miguel el Grande, y en algunos otros pueblos [...]", lo que obviamente fue motivado por la intención de debilitar el movimiento insurgente. ${ }^{126}$

Aun antes de que el virrey novohispano publicara el decreto con la abolición del tributo de indios, el Acta de Constitución del Estado Libre e Independiente del Socorro - en Nueva Granada-, del 15 de agosto de 1810, declaró la abolición del tributo de indios y la repartición de las tierras de los resguardos indios entre ellos (sin la posibilidad de reventa durante los siguientes 25 años) y, el 24 de septiembre, la Junta Suprema de Bogotá legisló la abolición

\footnotetext{
125 Alamán, Historia de México, t. I, pp. 364-365; Granados, "Huérfanos”, pp. 299-301, n. 30.

126 Bando del virrey. Por lo mismo, Van Young no encuentra ejemplos de levantamientos posteriores a 1810 en los pueblos novohispanos relacionados con el pago de impuestos. VAn Young, The Other Rebellion, p. 410.
} 
del tributo de indios y la repartición de las tierras de los resguardos - sin mencionar el tema de la reventa- ${ }^{127}$ En el territorio novogranadino de Pastos, colindante con la Audiencia de Quito, de donde habían salido muchos indios en apoyo a los realistas en la represión de la Junta quiteña de 1809 , se les ofreció una reducción en el tributo en 1810, principalmente para asegurar su lealtad, pero los tributarios la rechazaron con el argumento de que querían seguir apoyando al rey. ${ }^{128}$

127 Mayorga García, "La extinción”, pp. 60-61. Desde 1809, el cabildo de Socorro había propuesto al diputado de la Nueva Granada a la Junta Suprema que se aboliera el tributo de indios, se repartieran las tierras comunales de los resguardos y que los indios pagaran los impuestos que tocaban a los demás. Cabe notar que para el "Ilustre Cabildo", los indios "por lo común [...] son estúpidos y tan pobres que parece no entienden sus ideas más allá del momento presente". Instrucción que da el Muy Ilustre Cabildo, arts. 1 y 3. El cabildo de Santa Fe refiere a "un ignominioso tributo que le impuso la injusticia y la sinrazón" y la Instrucción enviada de Valencia proponía no específicamente la eliminación del tributo, sino que los pocos indios que vivían en algunos de los pueblos se convirtieran en españoles de manera que se vendieran sus tierras "a cuenta de S.M.” y comenzaran a pagar los impuestos correspondientes a los españoles. Representación del Cabildo de Santa Fe; Instrucción arreglada por el teniente justicia mayor.

128 Gutiérrez Ramos, “Acción política”, pp. 13-14. El siguiente año, el gobernador de Popayán redujo el tributo de los indios en Pastos y en 1812 el cabildo de la ciudad de Pasto condonó uno de los dos pagos anuales a los indios que habían luchado en defensa del rey. El siguiente año, 1813, sin embargo, el gobernador de Popayán le advirtió al presidente de la Audiencia de Quito (de la que dependía en aquel momento álgido de las guerras de independencia) que ante la proclamación de la Constitución de 1812 que confirmaba la abolición del tributo, le sería imposible cobrárselo a los indígenas sin una presencia armada. GuTIÉRREz RAMOs, "Acción política”, pp. 13-14. 
En febrero de 1811 la Junta Gubernativa de Chile declaró la abolición del tributo de indios, ${ }^{129}$ un mes antes del decreto de las Cortes gaditanas que amplió la eliminación del tributo, tanto de indios como de castas - retomando lo hecho por Venegas -, al resto de América. ${ }^{130}$ En abril de 1811, el capitán general de Guatemala - a sabiendas de las inquietudes de algunos pueblos de indios en las regiones fronterizas con la Nueva España donde el tributo se había eliminado- ordenó reducirlo a los niveles existentes antes de la nivelación del mismo que se había impuesto en 1802 en concordancia con lo indicado en la ordenanza de intendentes. ${ }^{131}$

El 1ํ de septiembre de 1811 la Junta Provisional Gubernativa de las Provincias de Río de la Plata declaró la abolición del tributo de indios y el 2 de septiembre (obviamente sin conocer la decisión de Buenos Aires) la Junta Provincial Gubernativa de Salta, de manera autónoma, también la declaró. ${ }^{132}$ Según el análisis de Doucet, los miembros de la Junta Provisional tomaron esta decisión para atraer a su causa a los indígenas en el Alto Perú, donde el Ejército Auxiliar del

129 Enríquez, “La República chilena”, p. 631. Doucet nota que entre los considerandos que anteceden el decreto, se menciona el poco ingreso proveniente del tributo. Doucet, “La abolición”, p. 143. Dos años después, en 1813, se declaró la abolición de las repúblicas de indios y de las tierras comunales; así mismo se decretó la venta de las tierras de los indios para financiar su reubicación (con bueyes, tierras, semillas, arado y telares) en “villas" establecidas en algunos de los pueblos. Enríquez, "La República chilena”, p. 639.

130 Sobre el debate, o más bien la sorpresiva ausencia de debate, en las Cortes gaditanas sobre la abolición del tributo, véase Granados, "Huérfanos”, pp. 300-304.

131 Fernández Molina, Los tributos, pp. 30-33.

132 Doucet, “La abolición”, pp. 133 y 152. 
Perú apenas había sufrido una pérdida ante las fuerzas realistas, y no tanto - como el mismo decreto indicó- porque el tributo "oprimía más su corazón que a sus amados hermanos que $1[\mathrm{o}]$ arrastraban”. ${ }^{133}$ Como señaló Sánchez Albornoz hace casi 40 años y como Doucet lo subrayó hace más de 20, el hecho de que aún pocos meses antes del decreto, líderes bonaerenses como Pueyrredón y Castelli se encontraban organizando el cobro del tributo en el Alto Perú pone de relieve la importancia respectiva de las convicciones ideológicas y la conveniencia político militar de la misma decisión de abolir el tributo. ${ }^{134}$ El decreto de la Junta en Salta también obedecía a la coyuntura de guerra y, aunque no lo señalaba de manera directa, el documento implicaba la prestación forzosa del servicio militar, que fue resistido, como lo fue también el pago del tributo rezagado. ${ }^{135}$

Desde octubre de 1811, cuando las primeras noticias de la abolición del tributo se dieron a conocer en Perú y antes de que oficialmente entrara en vigor, muchos yanaconas en la intendencia de Trujillo comenzaron a dejar de trabajar y ausentarse de las haciendas al considerar que sin la obligación de pagar el tributo - que los hacendados cumplían por ellos-, se había terminado su vínculo con las haciendas. ${ }^{136}$ Asimismo, el entonces presidente interino de la Audiencia de Cuzco, Mateo Pumacahua -famoso por su papel importante en la victoria sobre las tropas de Túpac Amaru y por reprimir la junta de La Paz en 1809-, frenó la eliminación

\footnotetext{
${ }^{133}$ Doucet, “La abolición”, p. 144.

134 Sánchez Albornoz, Indios, pp. 187-88; Doucet, "La abolición", p. 152.

${ }_{135}$ Doucet, "La abolición”, pp. 170-173.

136 Sala i Vila, $Y$ se armó, pp. 191-225.
} 
del tributo por considerar que sin él y la mita los caciques no tendrían función alguna en el sur andino. ${ }^{137}$

José de Bustamante, el jefe político del reino de Guatemala, publicó la eliminación del tributo finalmente en enero de 1812 y argumentó que no lo había hecho con anterioridad porque no había recibido aviso formal de su abolición. ${ }^{138}$ Bustamante publicó la supresión del tributo de indios después de unas protestas violentas en algunos de los pueblos principales en el altiplano guatemalteco y en medio de una serie de levantamientos urbanos en las principales ciudades del reino. ${ }^{139}$ En su decreto, el jefe político repitió el mismo tono e intención contrainsurgente utilizada por el virrey Venegas en la Nueva España y aclaró que su aplicación dependía de la lealtad de los indígenas. ${ }^{140}$

Citando los daños que el tributo les había causado a los indios, la Suprema Junta de Gobierno de Cartagena lo eliminó a partir del primero de julio de $1812 .{ }^{141}$

TIEMPOS INCIERTOS: EN SUSTITUCIÓN DEL TRIBUTO

A partir de 1810, el contexto hispanoamericano se encontró dominado, aunque con variaciones regionales muy marcadas, por dos cuestiones que se entrelazaron de tal manera que distinguirlas resulta casi imposible: las guerras independentistas y las reformas liberales. Como se ha descrito hasta el momento, este contexto informó las decisiones tomadas

\footnotetext{
137 O’Phelan, "Presentación”, p. 421.

${ }^{138}$ Fernández Molina, Los tributos, p. 33.

139 Pollack, “Totonicapán”, pp. 199-200.

140 Fernández Molina, Los tributos, p. 33.

${ }^{141}$ Meisel, "La crisis fiscal”, pp. 390-391.
} 
por los gobiernos realistas, independentistas o autonomistas. Fue en medio de la guerra, o en el amplio contexto de las guerras de independencia hispanoamericanas, que los gobiernos e insurgencias eliminaron el cobro de un derecho señorial - a veces necesario para el sustento de los diferentes gobiernos y movimientos armados - que pagaban los vasallos y, a menudo, comenzaron a aplicar una "contribución" que frecuentemente tomaba la forma de una capitación, cuyas condiciones para los contribuyentes/ciudadanos eran muy similares a las que poco tiempo antes habían experimentado los tributarios/vasallos.

Con la eliminación del tributo por parte del Consejo de Regencia y su posterior confirmación por las Cortes de Cádiz, los gobiernos realistas que lograron mantener un control territorial total o significativo, como los de Venegas y Calleja en Nueva España, Abascal en Perú (y Alto Perú) y Bustamante en el reino de Guatemala, tuvieron que adecuarse a esta nueva realidad fiscal. En particular, los gobiernos de Perú y Guatemala enfrentaron dificultades más agudas porque el tributo proveía una parte más significativa de sus ingresos. De igual manera, los insurgentes en la Nueva España, en su búsqueda de ingresos que permitieran el funcionamiento de su gobierno, debieron aplicar contribuciones en la forma del impuesto de capitación, entre otras. La Junta Gubernativa Provisional de las Provincias de Río de la Plata, en su afán de tomar el control del Alto Perú, quería utilizar la eliminación del tributo como mecanismo para facilitar el acercamiento de los indígenas a su causa, puesto que, en la medida en que el Alto Perú estuviera bajo el control del virrey peruano, el tributo le aportaría muy pocos ingresos al erario rioplatense. 
En Nueva Granada y Chile, como ocurrió en Río de la Plata (excluyendo al Alto Perú, controlado desde Lima), los ingresos del tributo eran mínimos y en estos territorios el discurso liberal compaginaba con intentos por tener acceso a las tierras de los pueblos de indios. Los diferentes gobiernos que regían la Audiencia de Quito entre 1811 y 1814 - fueran éstos autonomistas o realistas - nunca publicaron el decreto de la eliminación del tributo por temor a las implicaciones que habría tenido para el erario. ${ }^{142}$

Ante la eliminación del tributo, las autoridades españolas en los territorios que dependían, de manera parcial pero significativa (a veces muy significativa), de esta fuente para sostener sus aparatos gubernamentales, enfrentaron la necesidad de buscar otras maneras de reemplazar el faltante. En el reino de Guatemala, el entonces jefe político José de Bustamante redujo la tasa de interés sobre los bonos de gobierno y gastó todo el dinero de los fondos de las cajas de comunidad de los pueblos de indios, además de imponer contribuciones voluntarias (como lo hizo también Venegas en la Nueva España) sobre los criollos. Aunque no ha habido estudios sobre su impacto real, Bustamante estableció también una "contribución voluntaria" en abril de 1812 que debía aplicarse a los indígenas y que preveía una integración anual al erario real de 2 pesos por cada "contribuyente", la cantidad que se había asignado para el tributo en la ordenanza de intendencias. Adicionalmente realizó recortes muy

\footnotetext{
142 Morelli, Territorio, p. 170. Igualmente, en la provincia neogranadina de Pasto, que colindaba con la Audiencia de Quito y en donde dominaban - en general - los realistas, nunca se publicó la eliminación del tributo indio decretada por las Cortes de Cádiz. Gutiérrez Ramos, “Constitución”, pp. 215 y 222.
} 
fuertes en el presupuesto e incluso rechazó subrogar los gastos relacionados con el viaje y viáticos de los representantes americanos en Cádiz y los reasignó a los ayuntamientos. ${ }^{143}$

En Perú, el virrey Abascal se esforzó por aumentar los ingresos provenientes de otros impuestos como aquellos aplicados sobre el comercio ultramarino, el tabaco, y aún pensó en darles tierras a los indígenas a cambio del cobro de un canon. ${ }^{144}$ Ante la incertidumbre en torno a los impactos de estas iniciativas, Abascal intentó implementar una "contribución provisional voluntaria”, que se habría presentado a los indígenas como una opción que podía escogerse en vez de pagar los impuestos que correspondían a las demás clases. ${ }^{145}$ Ante el rechazo hacia esta contribución por parte de la Audiencia y de otros sectores de la sociedad, Abascal optó por implementar otra en 1812, con características similares, bajo el nombre de "donativo ordinario", que quiso justificar por medio de documentación que demostraba el apoyo de las autoridades indígenas. No obstante la resistencia de muchos pueblos y el cuestionamiento público que el defensor Eyzaguirre desarrolló hacia las fuentes utilizadas para sustentar la supuesta anuencia de los indígenas, Abascal aplicó con relativo éxito el donativo ordinario hasta el regreso de Fernando VII y el establecimiento de la llamada "contribución" que fue en la práctica una continuación del tributo de indios y castas. ${ }^{146}$ Según Sala i Vila, al aplicar la

143 Wortman, Government, pp. 209-210.

144 Sala i Vila, Y se armó, pp. 171, 248-249; Glave, "Cultura política”, p. 406.

145 Sala i Vila, Y se armó, pp. 173; Soux, “Tributo”, n. 21, p. 29.

146 Contreras, “El impuesto”, pp. 70-71; Glave, "Cultura política”, pp. 396-411. 
contribución impuesta por Abascal, las autoridades locales amenazaron a los indígenas estableciendo que si no lo pagaban perderían sus tierras, ${ }^{147}$ lo que resulta un planteamiento similar al cobro de un canon que Abascal había propuesto antes de implementar la contribución y compagina con la noción del quid pro quo de tributo por acceso a la tierra que se ha discutido en este texto.

Durante la rebelión llamada de Cuzco - que se dio en varias intendencias del sur de Perú y aun en partes del Alto Perú entre 1814 y 1815 -, ante la falta de otros insumos que pudieran cubrir los costos asociados a la guerra, las autoridades insurgentes inicialmente cobraron la contribución que Abascal había impuesto a los indígenas, por lo menos en las zonas más cercanas a Cuzco. ${ }^{148}$ En octubre de 1815, durante la última y más radical fase de la rebelión, los líderes abolieron la contribución para todos los pueblos adheridos a su movimiento. ${ }^{149}$

En la Nueva España, la insurgencia provocó problemas graves para la Real Hacienda mucho más allá de los ingresos perdidos por la eliminación del tributo y, como ocurrió con los rioplatenses que buscaban aprovechar la situación para afianzar el apoyo de los indígenas altoperuanos, los alzados intentaban utilizar un sistema fiscal que acrecentara el apoyo popular. Sin embargo, la insurgencia necesitaba financiar la guerra - y mantener a los párrocos -, por lo que implementó, progresivamente, un sistema fiscal que se basaba en la alcabala, la contribución directa y lo producido

147 Sala i Vila, $Y$ se armó, pp. 184-185.

148 Sala i Vila, $Y$ se armó, pp. 238-239.

149 Sala i Vila, $Y$ se armó, p. 244. 
en las tierras nacionalizadas de sus opositores. El gobierno de la "América mexicana" redujo la tasa pagada en concepto de alcabala, pero comenzó a cobrárselo a los indígenas, quienes se resistieron y lograron que se les exentara. Al eliminar el tributo, los insurgentes inicialmente aplicaron una capitación que contemplaba pagos diferenciados para los indígenas y las demás clases y por fin llegaron, en agosto de 1815, a aplicar una contribución directa, proporcional, que consideraba seis rangos de ingreso. ${ }^{150}$

El sistema implementado por Morelos y sus seguidores se desarrolló al mismo tiempo al nuevo sistema virreinal y, como bien indica Serrano, "[l]os insurgentes y realistas no fueron espejos, sino esponjas que en muchas ocasiones se alimentaron mutuamente". ${ }^{151}$ Los nuevos sistemas fiscales se nutrieron de un interés común en aplicar reformas que eliminaran los privilegios (y, se entiende, las diferencias), que era un tema que se había discutido ampliamente dentro de la Monarquía española y que la crisis de ésta abrió pauta para aplicar.

\section{LAS PRIMERAS “CONTRIBUCIONES DIRECTAS”}

La contribución directa planteada por las Cortes de Cádiz, y luego las muchas que se aplicaron en Hispanoamérica en las siguientes décadas, tenían raíces profundas en el siglo XviII español ${ }^{152}$ y de alguna manera se alimentaron de otras experiencias europeas, las cuales no se desarrollaron de manera

150 Serrano Ortega, "El sistema fiscal".

151 Serrano Ortega, "El sistema fiscal", p. 79.

152 López Castellano, Liberalismo, pp. 27-88. 
independiente, sino siempre en referencia con los experimentos y logros de los demás países. ${ }^{153}$ Nutrida de la aplicación, tras la guerra de la sucesión española, de los Decretos de Nueva Planta en los territorios que conformaban el reino de Aragón, y de los esfuerzos periódicos y bien desarrollados - aun cuando siempre fallidos - a partir de 1749 para crear una "contribución única" en Castilla, la contribución extraordinaria de guerra fue decretada por la Junta Central de Sevilla en enero de 1810 y luego modificada el primero de abril de 1811 por las Cortes gaditanas, de forma

${ }^{153}$ Mientras hay una larga historia de impuestos graduados - algunos de los cuales se han mencionado anteriormente-, el primer ejemplo de un impuesto progresivo que se aplicó a la tierra y otras formas de riqueza lo encontramos en Florencia en 1442, que se mantuvo hasta el siglo xviII. Isenmann, "Medieval", pp. 48-52. El tema de la igualdad fiscal aplicada a la monarquía francesa comenzó a tener un auge a finales del siglo XvII y principios del xviII; la capitation francesa de 1695 se estableció con la noción de su aplicabilidad universal y con una graduación severa basada en la supuesta riqueza correspondiente a la ubicación del individuo en una de las 569 categorías que se establecieron, aunque en la práctica las exenciones florearon. Guery, "État". Sólo en la segunda mitad del siglo xviII se creó la idea de la "progresividad" en los impuestos y comenzó a considerarse la aplicación de impuestos con esta característica. En 1787 y 1788 el abate Sieyes había escrito sobre la creación de un impuesto progresivo basado en la renta (como la propuesta de las Cortes gaditanas). BonNey, "Early", p. 205 y "Revenues", pp. 485-486. En 1793 el gobierno revolucionario francés aplicó, por una sola vez, un préstamo forzoso con tasas progresivas (hasta $70 \%$ para el bando más alto de ingreso) y en 1798 y 1800 se aplicó un impuesto progresivo sobre la renta en los Países Bajos. Bonney, "Revenues”, pp. 485-486. El impuesto sobre la renta (income tax) se había implementado por primera vez en el Reino Unido en 1799 en el contexto de las guerras napoleónicas pero se abolió al terminar éstas y recibió muchas críticas por estar de alguna manera vinculado al pensamiento de la revolución francesa y por pretender igualar las riquezas. Bonney, “Revenues”, pp. 486-488. 
que el impuesto se aplicara de manera progresiva y, entonces, más equitativa. ${ }^{154}$ Dos años más tarde, en septiembre de 1813, las Cortes generales y extraordinarias decretaron el "nuevo plan de contribuciones públicas" que fue el sistema que debió reemplazar el existente, en concordancia con lo planteado en la Constitución doceañista. A diferencia de las anteriores propuestas de reforma fiscal en la Monarquía española, la contribución directa aplicaba una tasa progresiva sobre los ingresos de todos los españoles, sin excepción; además logró decretarse, aunque en la práctica tuvo poco éxito.

En la Nueva España, después de consultas con las autoridades principales del virreinato, se aprobó, en noviembre de 1813, la aplicación de una "contribución directa general y extraordinaria” tasada con base en el ingreso, que tuvo muy poco éxito en su aplicación, principalmente por la resistencia que encontró desde su inicio, en parte manifiesta en el rechazo hacia la elaboración de las declaraciones sobre el ingreso que el decreto sobre la contribución exigía y en la entrega de declaraciones con datos claramente falsos. ${ }^{155}$ Tras estas acciones, y con argumentos más claros que criticaban la contribución directa por recaer en su mayoría en los grupos sociales con más ingresos, se puede ver que

154 López Castellano, Liberalismo, n. 249, p. 270. Uno de los cuatro apartados de las Instrucciones enviadas por el ayuntamiento guatemalteco a su diputado en las Cortes gaditanas se intitula "Proyecto de una contribución" (firmado el 12 de enero de 1812) y en él se planteó la universalidad del impuesto y un sistema de aplicación graduado - sin definir muy bien con base en qué criterios - y regresivo. Instrucciones para la constitución, pp. xi, 63-79.

155 SÁnchez Santiró, “La irrupción”, p. 23. Este tipo de dificultades en la aplicación de las contribuciones directas es bastante común. 
los sectores pudientes de la sociedad novohispana rechazaban la noción esbozada en la Constitución - retomada de la Declaración de los derechos del hombre y del ciudadanode que las personas que recibían más beneficios del Estado debían tomar un papel más activo en financiarlo. ${ }^{156} \mathrm{~A}$ diferencia de la contribución extraordinaria de guerra que se intentó asignar en la Península, el impuesto directo general y extraordinario que se aplicó en la Nueva España preveía una tasa ligeramente regresiva, ${ }^{157}$ tasas más bajas en general (en especial las que se aplicaban a las personas con ingresos más altos) y un nivel mínimo de ingresos mayor para ser susceptible a la obligación; esto último probablemente se pensó como mecanismo para asegurar el apoyo de los sectores más pobres durante la guerra.

En el contexto de la ley de la contribución directa aprobada por las Cortes y retomando de alguna manera la propuesta que el virrey Abascal había elaborado en torno al pago de un canon, en 1814 la diputación provincial de Lima propuso un impuesto sobre la tierra que habría implicado la división de las tierras de la comunidad entre sus miembros y a la vez reemplazado el tributo. La diputación limeña quería evitar que se considerara como una continuación del tributo

\footnotetext{
156 Serrano Ortega, Igualdad, pp. 34-38. El artículo XIII de la Declaración reza así: "Siendo necesaria, para sostener la fuerza pública y subvenir a los gastos de administración, una contribución común, ésta debe ser distribuida equitativamente entre los ciudadanos, de acuerdo con sus facultades".

157 Jáuregui, La Real Hacienda, p. 276; SÁnchez Santiró, “La irrupción”, p. 18.
} 
y prefería ver este nuevo cobro como un anticipo de la nueva contribución directa que quedaba por aplicarse. ${ }^{158}$

La Intendencia y Capitanía General de Yucatán merece una mención particular por los fuertes problemas fiscales que causaron la eliminación del ingreso proveniente de los situados y la abolición del tributo indio. A partir de 1800, la intendencia de Yucatán, a causa de las guerras napoleónicas, empezó a recibir de manera errática los 200000 pesos anuales que anteriormente había recibido en calidad de situados de diferentes cajas novohispanas, hasta dejar de percibirlos por completo a partir de $1808 .{ }^{159}$ En este contexto, la intendencia vivía una situación fiscal crítica al enfrentar la eliminación del tributo indio, que proveía más de 40\% de los ingresos de la hacienda provincial entre 1801 y $1810 .{ }^{160}$ Ante un panorama fiscal sumamente difícil, el intendente -actuando de manera independiente de sus superiores ante la dificultad de comunicación que la insurgencia había creado en el centro de la Nueva España - realizó consultas con las principales autoridades locales, en un ambiente de búsqueda de consenso similar al que se dio en las ciudades de México y Lima. ${ }^{161}$ Mediante estas discusiones y ante una crisis fiscal que se deterioraba constantemente después de dos años sin los ingresos del tributo, en abril de 1814 el intendente decidió abrir las puertas de la península yucateca

\footnotetext{
158 SALA I VILA, $Y$ se armó, pp. 248-249.

159 Quezada y Moreno Acevedo, "Del déficit”, pp. 326-327.

160 Sánchez Santiró, “Los impactos”, p. 17, cuadro.

161 Cobá Noh ha discutido algunos de los intercambios sobre la legalidad de los cobros del tributo, la comunidad, el medio real para ministros y el diezmo que demuestran las diferentes opiniones existentes sobre estos cobros. Совá NoH, El "indio ciudadano".
} 
al comercio con países amigos y neutrales; en noviembre de 1814, a sabiendas del regreso al trono de Fernando pero antes de que el monarca implementara la "contribución" que reemplazara el tributo indígena, decretó el restablecimiento de este cobro bajo el nombre de "contribución extraordinaria". 162

Después de su regreso al trono en 1814, Fernando VII ordenó el $1^{\circ}$ de marzo de 1815 el establecimiento de una "contribución" que reemplazara el tributo de indios y de castas en las provincias. El (r)establecimiento de la "contribución del Real tributo" 163 ocurrió en las regiones controladas por las autoridades leales a la Monarquía: principalmente el virreinato de Perú y las regiones cercanas, como el Alto Perú, que estuvieron bajo el mando de Lima; el reino de Guatemala; la Nueva Granada, aunque de manera poco exitosa por la guerra todavía en curso. ${ }^{164}$ En la Nueva España la nueva "contribución" jamás se aplicó, con la excepción de la intendencia de Yucatán. ${ }^{165}$

En Perú, Abascal recibió la noticia del restablecimiento del tributo con alegría y pidió refuerzos para evitar posibles levantamientos al recomenzar el cobro, mientras se quejaba de lo injusto que había sido eliminarlo. ${ }^{166}$ A partir de 1815, las autoridades peruanas aplicaron una "contribución de indígenas y castas", que se acompañó con otras reformas

\footnotetext{
162 Quezada y Moreno Acevedo, “Del déficit”.

163 En el reino de Guatemala se le llamaba así o bien "tributo”.

164 Mayorga García, “La extinción”, pp. 65-67.

165 Serrano Ortega, Igualdad, p. 79. En Oaxaca, por lo menos, existió un esfuerzo para que se implementara. Sánchez Silva, Indios, pp. 118-119.

166 Glave, “Cultura política”, p. 402.
} 
fiscales y se mantuvo hasta 1821. El gobierno peruano aplicó esta nueva "contribución" en 1815, durante la campaña para pacificar los restos de la rebelión de Cuzco, lo que seguramente influyó para que los rebeldes decidieran, como se ha mencionado antes, eliminarla.

En enero de 1816 se enviaron desde Cartagena copias de la cédula que (r)establecía la "contribución real” a los gobiernos que estuvieron bajo el control de los realistas en el Nuevo Reino de Granada, aunque algunos pueblos fueron exentados. ${ }^{167}$ La Audiencia de Quito comenzó a cobrar el tributo con más fuerza a partir de octubre de 1814 cuando los realistas retomaron la ciudad capital, y de inmediato el protector de naturales solicitó que a los indígenas de Pastos se les cobrara según la tasa reducida que se había aplicado desde 1811. La Audiencia quiteña aceptó la solicitud del protector de naturales en mayo de 1817, pero en este mismo año se eliminó por completo el tributo en Pastos, para asegurar la lealtad de la población indígena en un momento del nuevo auge independentista en Venezuela y Nueva Granada. ${ }^{168}$

En el reino de Guatemala no hay registros de modificaciones fiscales en el cobro de una contribución directa o capitación que incluyera a grupos sociales más allá de los indios. En el altiplano guatemalteco, el restablecimiento del tributo provocó resistencia desde 1816 y los pueblos de indios en el Partido de Totonicapán mantuvieron su rechazo

167 Mayorga García, “La extinción”, pp. 65-66.

168 Gutiérrez Ramos, “Acción política”, pp. 14-17. 
al pago durante los siguientes años, hasta que las tensiones estallaron en la rebelión de $1820 .^{169}$

El restablecimiento de la Constitución de 1812 después de la rebelión de Riego en 1820 provocó el momento más álgido del levantamiento de Totonicapán, porque los indios totonicapenses, que ya habían tomado el control efectivo de su pueblo desde hacía unos meses, consideraban que con ello el tributo se había eliminado de nuevo. En San Miguel Totonicapán, pueblo de indios y cabecera de la alcaldía mayor de Totonicapán, como también en la ciudad de Guatemala, el restablecimiento de la constitución se celebró el 9 de julio, día en que Fernando la juró antes las Cortes en Madrid; pero en Totonicapán fueron los indios líderes de la rebelión quienes organizaron las festividades, tomando formalmente el control de la cabecera y de los pueblos a su alrededor.

No obstante la interpretación que los totonicapenses le dieron al restablecimiento de la Constitución, el nuevo gobierno en España tuvo cuidado de no reafirmar la abolición del tributo: había entendido que, independientemente de los principios liberales, las necesidades fiscales en ciertas regiones de América hacían muy poco factible su eliminación. Para entonces, el tributo ya se había dejado de cobrar en la Nueva España - con la excepción de la península de Yucatán - mientras la recaudación seguía en el reino de Guatemala, la Audiencia de Quito y los territorios del Alto y Bajo Perú, controlados desde Lima.

En los siguientes años, con las independencias, el tributo se abolió en todas estas regiones gracias a los decretos

169 Pollack, Levantamiento. 
de Bolívar en América del Sur y a la anexión de Centroamérica al Imperio Mexicano en la América septentrional. Unos años después se aplicaron diferentes formas de "contribuciones directas" en casi todos los nuevos estados-nación, con variaciones muy significativas en distintos estados federados o departamentos. Mientras casi todas las "contribuciones directas" de esta época apuntaban a establecer cobros universales entre los contribuyentes, en muchos casos con tasas graduadas según el ingreso o el tipo de oficio en que trabajaba el individuo, los resultados variaron mucho y en las regiones con una presencia demográfica indígena importante las diferentes contribuciones se iban asemejando más a formas de capitación con un cobro único que, en la mayoría de los casos, solamente se aplicó a los indígenas. ${ }^{170}$

\section{CONSIDERACIONES FINALES}

A lo largo de su existencia, el tributo de indios y de castas fue un derecho señorial, sin paralelo exacto en el reino de Castilla, que se desarrolló a partir de las formas tributarias americanas existentes al momento de la invasión española. El tributo tomó una forma particular debido al periodo en el que se estableció: los esfuerzos que la monarquía española - como otras monarquías europeas - realizó para aumentar su poder en el proceso conocido como la formación de

\footnotetext{
${ }^{170}$ La bibliografía sobre el tema es extensa y a partir de ella estoy elaborando un artículo que da continuación a este trabajo. Como puntos de partida, se puede sugerir SÁnchez Albornoz, Indios; Jáuregui, De riqueza; Serrano Ortega, Igualdad; Escobar Ohmstede, "Del dualismo étnico".
} 
los estados modernos disminuyó la posibilidad de que se establecieran señoríos (con sus correspondientes derechos señoriales) y Cortes americanas (con sus capacidades de negociar con el rey y asegurar el cobro de los pechos). Desde su establecimiento en el siglo xvi, y hasta su eliminación en el siglo XIX, el tributo reprodujo la noción de las divisiones estamentales castellanas - y sus aspectos fiscales-, aunque con distinciones basadas en clases que se definían por su “calidad". Asimismo, el tributo se aplicó de manera que se retomara la noción fiscal medieval que distinguía entre tributarios y miembros de los cuerpos armados, con la consideración de que estos últimos fueran reconocidos con un estatus mayor. En las diferentes interpretaciones del "pacto colonial", el tributo siempre resultó ser lo que los indios debieron aportar para cumplir con sus obligaciones - lo que subraya su importancia-, indistintamente de si el rey les proporcionaba a cambio la justicia o la tierra.

Como uno de los nuevos vientos que el siglo xviII trajo al campo fiscal hispanoamericano, las reformas a los mecanismos del cobro del tributo, implementadas en el último tercio de la centuria, no sólo aumentaron los ingresos reales sino que también modificaron las relaciones dentro de las comunidades y los vínculos entre ellas y la burocracia española. Desde mediados del siglo xviII, la eliminación del tributo resultó ser un tema de discusión entre los reformadores que argumentaban sus consecuencias negativas para la economía y el erario real. La posible creación de una única contribución también ocupó a muchos reformadores españoles durante el siglo xviII, y aunque no se logró legislarla sino hasta la crisis de la Monarquía, los intentos previos impactaron en las contribuciones directas decretadas por 
las Cortes gaditanas y la insurgencia novohispana, las que a su vez influyeron en el establecimiento de contribuciones similares en los nuevos estados americanos.

No obstante la existencia de ideas que favorecían la abolición del tributo porque - se consideraba - reflejaba los tratos preferenciales de la sociedad corporativista, frenaba el crecimiento económico y reducía los ingresos fiscales, su eliminación se logró sólo en el contexto de la vacatio regis, de los procesos independentistas americanos y del pensamiento liberal y republicano que se difundía a los dos lados del Atlántico en las primeras décadas del siglo XIX. La eliminación del tributo se dio, en Cádiz y en las diferentes regiones americanas, por varias razones, que tuvieron una importancia distinta en los variados contextos: el espacio ideológico contemporáneo, los intereses sectoriales, las necesidades fiscales y el deseo de adquirir o mantener la lealtad de las personas sujetas a los cobros.

Las acciones tomadas en los diferentes territorios hispanoamericanos en torno a la eliminación del tributo entre 1809 y 1815 dieron señales importantes sobre las nuevas formas de contribución que se impusieron posteriormente en los nuevos estados nación. Aunque desconocemos el grado de efectividad que tuvo la contribución voluntaria en el reino de Guatemala, en las demás regiones de Hispanoamérica que más tarde aplicaron una contribución directa que se asemejaba a la capitación se había logrado mantener el tributo o implementar una nueva contribución similar en este periodo: la Audiencia de Quito nunca desistió de cobrar el tributo; en el Perú y el Alto Perú (gobernado desde Lima) se aplicó una nueva contribución a partir de 1812; aunque tarde, en la intendencia de Yucatán se impuso una 
nueva contribución en 1814. En Oaxaca se encuentra la única excepción parcial: en el periodo de noviembre de 1812 a marzo de 1814, durante el cual la intendencia estuvo controlada por las tropas insurgentes, se aplicó una capitación universal, sin distinciones de tipo étnico.

En los territorios donde la importancia demográfica de los indígenas era menor, como la mayor parte de Nueva Granada, Chile y Río de la Plata (con la exclusión del Alto Perú), se eliminó el tributo tempranamente y casi sin vuelta atrás. Al parecer, el interés de algunos sectores en deshacer las comunidades para dar acceso a sus tierras tuvo más importancia para los gobernantes de estos territorios que el poco ingreso que el tributo les redituaba.

Después del esfuerzo por sistematizar algunas de las informaciones y debates en torno al tributo, creo conveniente señalar ciertas deficiencias en la historiografía que pueden remediarse con futuras investigaciones: el tributo - como muchos de los temas vinculados con el mundo material - ha recibido poca atención en los últimos decenios y muchos de los estudios mejor desarrollados en este campo ya llevan décadas - más de medio siglo en algunos casos - desde su publicación inicial. Parece importante señalar que es un campo de investigación que debe retomarse y desarrollarse porque, como espero haber demostrado, abre importantes ventanas sobre muchos aspectos de la historia colonial hispanoamericana, además de que, como parte de una estructura fiscal con base estamental sobre la cual se erigieron los sistemas fiscales nacionales, ha tenido sus implicaciones para el desarrollo de las sociedades actuales. 
Como en muchos campos, la investigación sobre el tributo se beneficiaría de una mejor utilización de una perspectiva comparativa que permitiera analizar los procesos latinoamericanos dentro de un cuadro más amplio que hiciera referencia a los sistemas tributarios en otras partes del mundo; comenzar con estudios sobre los diferentes territorios de la Monarquía española pareciera ser un buen punto de partida. Las averiguaciones sobre el tributo indiano pueden beneficiarse de estudios precisos y locales, ${ }^{171}$ pero con conocimiento de cómo se sitúan dentro del abanico de las diversas realidades hispanoamericanas. Estas investigaciones pueden vincularse con los esfuerzos recientes por repensar las categorizaciones étnicas que han utilizado las matrículas y censos de finales del siglo XviII como insumos básicos. ${ }^{172}$

En relación con los estudios locales, se puede indagar más sobre las dinámicas del cobro dentro de las comunidades: ¿los tributarios dejaban el monto total del tributo al momento en que las autoridades entregaban el tercio o se cobraba por alguna otra temporalidad ${ }^{173}$ ¿Se aplicaba en la práctica el supuesto de que todos pagaban por igual o hubo más casos como los mencionados por Gibson, en que de alguna manera se modificaban las tasas según la capacidad económica del tributario? Así mismo, hace falta desarrollar

171 Se espera la publicación de los resultados de una investigación profunda sobre los tributos a lo largo del periodo colonial en Chiapas. ObaraSAEKI y ViqueIRA, El arte de contar.

172 Véanse, por ejemplo, los trabajos recientemente publicados en $E l$ Taller de Historia.

173 Hay algunas indicaciones en TANCK, Pueblos, p. 46 y Gutiérrez NúÑEz, "La Real Hacienda”, pp. 39-40. 
una mayor seguridad sobre los impactos reales de la movilidad de los tributarios y entender en cuáles regiones, en qué momentos y con qué éxito el tributo fomentaba la búsque$\mathrm{da}$ de ingresos por medio de trabajo remunerado.

\section{REFERENCIAS}

Actas de Cabildo

Actas de Cabildo de la Ciudad de México, México, Aguilar e Hijos, 1871, 50 tomos.

Ahmed, Ziauddin y Ziauddin Ahmad

"The Concept of Jizya in Early Islam", en Islamic Studies, 14: 4 (invierno 1975), pp. 293-305.

Alamán, Lucas

Historia de México, México, Victoriano Agüero y compañía, 1883, 5 tomos.

Almarza Villalobos, Ángel Rafael y Armando Martínez GARNICA (eds.)

Instrucciones para los diputados del Nuevo Reino de Granada y Venezuela ante la Junta Central Gubernativa de Espana y las Indias, Bucaramanga, Universidad Industrial de Santander, 2008.

Alonso Álvarez, Luis

“¿Qué nos queréis, castillas?’ El tributo indígena en las islas Filipinas entre los siglos XVI y XVIII", en Jahrbuch für Geschicte Lateinamerikas, 40 (2003), pp. 13-42.

"El tributo indígena en la consolidación de la Hacienda filipina, 1698-1800”, en Jahrbuch für Geschicte Lateinamerikas, 41 (2004), pp. 91-115. 
Angulo Teja, María del Carmen

"Los ingresos y gastos procedentes de las rentas provinciales, 1768-1784”, en Revista de Historia Económica, 20:3 (2002), pp. 479-507.

La Hacienda española en el siglo XVIII: las rentas provinciales, Madrid, Centro de Estudios Políticos y Constitucionales, 2002.

Arowolo, Edward A.

“The Taxation of Low Incomes in African Countries", en Staff Papers-International Monetary Fund, 15: 2 (1968), pp. 322-348.

BAKER, Colin

"Tax Collection in Malawi: an Administrative History, 18911972”, en The International Journal of African Historical Studies, 8:1 (1975), pp. 40-62.

Bando

Bando de don José María Ansorena publicado en Valladolid (Morelia), aboliendo la esclavitud, el pago de tributo y otras gabelas, en Hernández y Dávalos, 1878, vol. II, en HernánDEZ SILVA (coord.).

Bonilla, Heraclio (comp.)

Los Andes en la encrucijada. Indios, comunidades y Estado en el siglo XIX, Quito, Ediciones Libri Mundi, Enrique GrosseLuemern, Facultad Latinoamericana de Ciencias Sociales sede Ecuador, 1991.

Bonney, Richard

"Early Modern Theories of State Finance", en Bonney (ed.), 1995, pp. 163-229.

“Revenues”, en Bonney (ed.), 1995, pp. 423-505.

Bonney, Richard (ed.)

Economic Systems and State Finance, Oxford, Oxford University Press, 1995. 
BREWER, John

The Sinews of War: War and the English State, 1688-1783, Londres, Unwin Hyman Ltd., 1989.

BRow MAN, David L.

“Comments", en Current Anthropology, 26: 2 (abr. 1985), pp. 197-199.

Cahill, David

"Curas and Social Conflict in the Doctrinas of Cuzco, 17801814", en Journal of Latin American Studies, 16: 2 (1984), pp. 241-276.

From Rebellion to Independence in the Andes: Soundings from Southern Peru, 1750-1830, Amsterdam, Centro de Estudios y Documentación Latinoamericanos, 2002.

Calvo Stevenson, Haroldo y Adolfo Meisel Roca (eds.)

Cartagena de Indias en la independencia, Cartagena, Banco de la República, 2011.

Caravaglia, Juan Carlos

"Algunos aspectos preliminares acerca de la 'transición fiscal' en América Latina: 1800-1850”, en Illes i Imperis, 13 (2010), pp. 159-192.

CARMack, Robert M.

The Quiche Mayas of Utatlan: The Evolution of a Highland Guatemala Kingdom, Norman, University of Oklahoma Press, 1981.

Castañeda García, Rafael

"Hacia una sociología fiscal. El tributo de la población de color libre de la Nueva España, 1770-1810", en Fronteras de la Historia, 19: 1 (ene.-jun. 2014), pp. 152-173.

Castañeda Delgado, Paulino

"Un problema ciudadano: la tributación urbana", en Revista de Indias, 33 (ene. 1973), pp. 493-550. 
Castillo Fernández, Javier

"Incidencia de la fiscalidad en la segunda repoblación del reino de Granada (1570-1600)", en Chronica nova. Revista de Historia Moderna de la Universidad de Granada, 25 (1998), pp. 213-226.

Castillo Rubio, Juan Manuel

"El tejido productivo en la Sevilla de mediados del xvi: un análisis demográfico y socioeconómico a partir de los padrones de moneda forera de las collaciones de Santa Catalina y San Román de 1548", en Historia y Genealogía. Revista de estudios bistóricos y genealógicos, 4 (2014), pp. 235-286.

СовÁ NoH, Lorgio

El "indio ciudadano". La tributación y la contribución personal directa en Yucatán, 1786-1825, México, Instituto de Investigaciones Dr. José María Luis Mora, 2009.

Connaughton, Brian (coord.)

1750-1850: la independencia de México a la luz de cien años, México, Universidad Autónoma Metropolitana-Iztapalapa, Ediciones del Lirio, 2010.

Connaughton, Brian, Carlos Illades y Sonia Pérez Toledo (coords.)

Construcción de la legitimidad política en México, México, El Colegio de Michoacán, Universidad Autónoma Metropolitana, Universidad Nacional Autónoma de México, 1999.

Contreras, Carlos

"Estado republicano y tributo indígena en la Sierra Central en la post-independencia”, en Histórica, xin: 1 (jul. 1989), pp. 9-44.

"El impuesto de la contribución personal en el Perú del siglo xix”, en Histórica, xxix: 2 (2005), pp. 67-106. 
Copia de la declaración rendida

Copia de la declaración rendida por don Juan de Aldama en la causa que se le instruyó por haber sido caudillo insurgente. 20-21 de mayo de 1811, Documento XLIII del tomo vi de Documentos históricos mexicanos. Obra conmemorativa del primer centenario de la Independencia de México, en García (dir.), Revolución de Independencia. Documentos, Héctor Cuauhtémoc Hernández Silva (coord.), México, Universidad Autónoma Metropolitana-Azcapotzalco.

Cullen Young, T.

"East African Tax-Method Revision", en Journal of the Royal African Society, 35: 141 (1936), pp. 381-385.

Chassin, Joëlle

"Protecteur d'Indiens contre Vice-Roi: la lutte de Miguel de Eyzaguirre pour l'abolition du tribut au Pérou”, en Cabier des Amériques Latines, 13 (1992), pp. 61-74.

D’Altroy, Terrence y Timothy Earle

"Staple Finance, Wealth Finance, and Storage in the Inka Political Economy", en Current Anthropology, 26: 2 (abr. 1985), pp. 187-206.

Dean, Trevor

"Wealth Distribution and Litigation in the Medieval Italian Countryside: Castel San Pietro, Bologna, 1385”, en Continuity and Change, 17: 3 (2002), pp. 333-350.

Diario

Diario de las discusiones y actas de las Cortes, Cádiz, Imprenta Real, 1811, t. III.

Díaz Rementería, Carlos J.

"En torno a un aspecto de la política reformista de Carlos III: las matrículas de tributarios en los virreinatos de Perú y Río de la Plata”, en Revista de Indias, xxxviI (1977), pp. 51-139. 
"El régimen jurídico del ramo de tributos en Nueva España y las reformas peruanas de Carlos III", en Historia Mexicana, XxviII: 3 (111) (ene.-mar. 1979), pp. 401-438.

Don José Simeón de Uría

Don José Simeón de Uría, da parte al ayuntamiento de Guadalajara de los movimientos de las fuerzas del señor Hidalgo, Arroyo Zarco, 21 de septiembre de 1810, Documento 37 del tomo in de la Colección de documentos para la Historia de la Guerra de Independencia de 1810 a 1821, en HernándeZ y DÁvalos, Revolución de Independencia. Documentos, Héctor Cuauhtémoc Hernández Silva (coord.), México, Universidad Autónoma Metropolitana-Azcapotzalco, CD-ROM, 2010.

Doucet, Gastón Gabriel

"La abolición del tributo indígena en las Provincias del Río de la Plata: indagaciones en torno a un tema mal conocido", en Revista de Historia del Derecho, 21 (1993), pp. 133-207.

Dougnac Rodríguez, Antonio

Manual de Historia del Derecho Indiano, México, Universidad Nacional Autónoma de México, 1994.

EICHELGRUN, G.

"Income-Tax in British Colonies", en The Economic Journal, 58: 229 (mar. 1948), pp. 128-132.

EnRíQuez, Lucrecia Raquel

"La República chilena ante la cuestión indígena (1810-1830)", en Hispania Sacra, 63: 128 (2011), pp. 627-652.

Escobar Ohmstede, Antonio

"Del gobierno indígena al ayuntamiento constitucional en las Huastecas hidalguense y veracruzana, 1780-1853”, en Estudios Mexicanos, 12: 1 (1996), pp. 1-26.

"Del dualismo étnico colonial a los intentos de homogeneidad en los primeros años del siglo xix latinoamericano", en Escobar Ohmstede, Falcón y Buve (coords.), 2010, pp. 41-57. 
Escobar Ohmstede, Antonio, Romana Falcón y Raymond Buve (coords.)

La arquitectura bistórica del poder. Naciones, nacionalismos y estados en América Latina. Siglos XVIII, XIX y XX, México, El Colegio de México, Centro de Estudios y Documentación Latinoamericano, 2010.

Escobedo Mansilla, Ronald

"El tributo de los zambaigos, negros y mulatos libres en el virreinato peruano”, en Revista de Indias, XLI (1981), pp. 43-54.

Espinosa, Aurelio

“The Spanish Reformation: Institutional Reform, Taxation, and the Secularization of Ecclesiastical Properties under Charles V", en The Sixteenth Century Journal, 37: 1 (primavera de 2006), pp. 3-24.

FatTAL, Antoine

Le statut legal des non-musulmans en pays d'Islam, Beirut, Dar-el Machreq Sarl Éditeurs, 1995.

Fernández Molina, Manuel

Los tributos en el reino de Guatemala: 1786-1821, Guatemala, Universidad de San Carlos de Guatemala, 2000.

Fonseca, Fabián de y Carlos de Urrutia

Historia general de Real Hacienda, México, Vicente G. Torres, 1845 , t. 1.

Fortea Pérez, José Ignacio

"Reino y Cortes: el servicio de millones y la reestructuración del espacio fiscal en la Corona de Castilla (1602-1621)", en Fortea Pérez y Cremades Griñan (eds.), 1993.

Fortea Pérez, José Ignacio y Carmen María Cremades Griñan (eds.) Política y hacienda en el antigno régimen, Murcia, Universidad de Murcia, 1993. 
García, Genaro (dir.)

Revolución de Independencia. Documentos, Héctor Cuauhtémoc Hernández Silva (coord.), México Universidad Autónoma Metropolitana-Azcapotzalco, CD-ROM.

García Peláez, Francisco de Paula

Memorias para la historia del antiguo reino de Guatemala, Guatemala, Sociedad de Geografía e Historia de Guatemala, t. II, 1972.

García PÉrez, Rafael

"El régimen tributario en las intendencias novohispanas: la ordenanza para la formación de los autos de vistas, padrones y matrículas de Revillagigedo II", en Anuario Mexicano de Historia del Derecho, XI-XII (1999-2000), pp. 279-307.

"Modernidad en el Antiguo Régimen: el problema del Estado (o el Estado como problema)", en Memoria y civilización, 6 (2003), pp. 43-96.

Gelabert, Juan

“The Fiscal Burden”, en Bonney (ed.), 1995, pp. 539-576.

Gibson, Charles

The Aztecs Under Spanish Rule: A History of the Indians of the Valley of Mexico 1519-1810, Stanford, Stanford University Press, 1964.

Glave, Luis Miguel

"Cultura política, participación indígena y redes de comunicación en la crisis colonial. El virreinato peruano, 1809-1814”, en Historia Mexicana, LVIII: 1(229) (jul.-sep. 2008), pp. 369-426.

Goldberg, P.J.P.

"Urban Identity and the Poll Taxes of 1377, 1379, and 1381", en The Economic History Review, 43: 2 (1990), pp. 194-216. 
González Enciso, Agustín

"La Hacienda castellana y la economía en el siglo xviII", en Estudis. Revista de historia moderna, 29 (2003), pp. 21-41.

Grafe, Regina y Alejandra Irigoin

"A Stakeholder Empire: The Political Economy of Spanish Imperial Rule in America", en Economic History Review, 65:2 (2012), pp. 609-651.

Granados, Luis Fernando

"Cosmopolitan Indians and Mesoamerican Barrios in Bourbon Mexico City: Tribute, Community, Family and Work in 1800", tesis de doctorado en historia, Washington, D.C., Georgetown University, 2008.

"Huérfanos, solteros, súbditos neoclásicos. Microhistoria de la abolición del tributo en el imperio español", en ConNAUGHTON (coord.), 2010.

Guasti, Niccolò

"Clergy and Fiscal Reform in Eighteenth-Century Spain", en Cromobs, Cyber Review of Modern Historiography, 19 (2014), pp. 18-49.

Guery, Alain

"État, classification sociale et compromis sous Louis XIV: la capitation de 1695", en Annales. Histoire, Sciences Sociales, 41:5 (1986), pp. 1041-1060.

Gudmunson, Lowell y Justin Wolfe (eds.)

Blacks and Blackness in Central America: Between Race and Place, Durham, Duke University Press, 2010.

Gutiérrez Álvarez, Coralia

"Racismo y sociedad en la crisis del Imperio Español. Los pueblos de los altos de Guatemala", en Webre y Herrera (eds.), 2014, pp. 249-277. 
Gutiérrez Núñez, Netzahualcóyotl Luis

"La Real Hacienda y la Ordenanza de Intendentes de 1786: ensayo sobre su estructura y funcionamiento a partir del caso de Valladolid de Michoacán: 1786-1820”, en Silva Riquer (coord.), 2015.

Gutiérrez Ramos, Jairo

"Acción política y redes de solidaridad étnica entre los indios de Pasto en tiempos de la independencia”, en Historia Crítica, 33 (2007), pp. 10-37.

"La Constitución de Cádiz en la provincia de Pasto, virreinato de la Nueva Granada, 1812-1822", en Revista de Indias, LXVIII: 242 (2008), pp. 207-224.

HARING, C. H.

El imperio español en América, México, Consejo Nacional para la Cultura y las Artes, Porrúa, 1990.

Hassig, Ross

Comercio, tributo y transportes. La economía política del Valle de México en el siglo XVI, traducción de Juan José Utrilla, México, Alianza Editorial Mexicana, 1990.

Heredia, Edmundo A.

"Los tributos indígenas en el siglo XIX", en Revista de la Junta Provincial de Historia de Córdoba, 5 (1977), pp. 59-66.

Hernández Silva, Héctor Cuauhtémoc (coord.)

Revolución de independencia Documentos, México, Universidad Autónoma Metropolitana-Azcapotzalco, CD-ROM, 2010.

Hernández y Dávalos, Juan E.

Colección de documentos para la historia de la Guerra de Independencia de México de 1808 a 1821, México, Imprenta José María Sandoval, 1878, 6 tomos. 
Hidalgo, Jorge

"Complementariedad ecológica y tributo en Atacama (16831792)”, en Estudios Atacameños, 7 (1984), pp. 311-325.

\section{Instrucciones}

Instrucción arreglada por el teniente justicia mayor de Valencia y alcalde segundo, acerca de los objetos e intereses nacionales, para informe del vocal y diputado de la provincia ante la Junta Suprema Central y Gubernativa, Valencia, 29 de julio de 1809, en Almarza Villalobos y Martínez GarniCA (eds.), 2008, pp. 251-266.

Instrucción que da el Muy Ilustre Cabildo, Justicia y Regimiento de la Villa del Socorro al Diputado del Nuevo Reyno de Granada a la Junta Suprema y Central Gubernativa de España e Indias, Socorro, 20 de octubre de 1809, en Almarza Villalobos y Martínez Garnica (eds.), 2008, pp. 127-138.

Instrucciones para la constitución fundamental de la monarquia española y su gobierno, Guatemala, Editorial del Ministerio de Educación Pública, 1953.

IrURozQui, Marta

"Las paradojas de la tributación. Ciudadanía y política estatal indígena en Bolivia, 1825-1'900”, en Revista de Indias, LIX: 217 (1999), Madrid, pp. 705-740.

"Sobre el tributo y otros atributos ciudadanos: sufragio censitario, fiscalidad y comunidades indias en Bolivia, 1825-1839", en Bicentenario. Revista de Historia de Chile y América, 5: 2 (2006), pp. 35-66.

IsENMANN, Eberhard

"Medieval and Renaissance Theories of State Finance", en BonNey (ed.), 1995, pp. 21-52.

Jamal, Vali

“Taxation and Inequality in Uganda, 1900-1964", en The Journal of Economic History, 38: 2 (jun. 1978), pp. 418-438. 
Jaramillo Magaña, Juvenal

Hacia una Iglesia beligerante. La gestión episcopal de fray Antonio de San Miguel en Michoacán, (1784-1804). Los proyectos ilustrados y las defensas canónicas, Zamora, El Colegio de Michoacán, 1996.

JÁuREgUi, Luis

La Real Hacienda de Nueva España: su administración en la época de los intendentes, 1786-1821, México, Universidad Nacional Autónoma de México, 1999.

“De re tributaria ¿Qué son las contribuciones directas?”, en JÁUREGUi (coord.), 2006, pp. 9-45.

JÁUREGUI, Luis (coord.)

De riqueza e inequidad. El problema de las contribuciones directas en América Latina, siglo XIX, México, Instituto de Investigaciones Dr. José María Luis Mora, 2006.

Jáuregui, Luis y José Antonio Serrano Ortega (coords.)

Las finanzas públicas en los siglos XVIII-XIX, México, Instituto de Investigaciones Dr. José María Luis Mora, 1998.

KLEIN, Herbert S.

"Fiscalidad real y gastos de gobierno", en Documento de Trabajo, 66, Lima, Instituto de Estudios Peruanos, 1994.

Konetzke, Richard

"La formación de la nobleza en Indias", en Estudios Americanos, 10 (1951), pp. 329-357.

"Sobre el problema racial en la América española", en Mundo Hispánico, 113-114 (1960), pp. 179-215.

La Lone, Mary B. y Darrell E. La Lone

"The Inka State in the Southern Highlands: state administrative and production enclaves", en Ethnohistory, 34: 1 (invierno 1987), pp. 47-62. 


\section{Ladero Quesada, Miguel Ángel}

"Estructuras y políticas fiscales en la Baja Edad Media", en Edad Media. Revista de Historia, 2 (1999), pp. 113-150.

LANGER, Erick D.

"Bringing the Economic Back In: Andean Indians and the Construction of the Nation-State in Nineteenth-Century Bolivia”, en Journal of Latin American Studies, 41: 3 (2009), pp. 527-551.

Larson, Brooke y Olivia Harris (eds.)

Ethnicity, Markets and Migration in the Andes: At the Crossroads of History and Anthropology, Durham, Duke University Press, 1995.

Lempérière, Annick

"Reflexiones sobre la terminología política del liberalismo", en Connaughton, Illades y Pérez Toledo (coords.), 1999, pp. 35-56.

Lira, Andrés

"El aspecto fiscal de la Nueva España en la segunda mitad del siglo xviII", en Jáuregui y Serrano Ortega (coords.), 1998, pp. 27-65.

Lokken, Paul

"Angolans in Amatitlan: Sugar, African Migrants, and Gente Ladina in Colonial Guatemala", en Gudmunson y Wolfe (eds.), 2010, pp. 27-56.

López Castellano, Fernando

Liberalismo económico y reforma fiscal. La contribución directa de 1813, Granada, Universidad de Granada, Fundación Caja de Granada, 1995.

Lorente Sariñena, María (coord.)

De justicia de jueces a justicia de leyes: hacia la España de 1870, Madrid, Consejo General del Poder Judicial, 2007. 
Maniau, Joaquín

Compendio de la historia de la Real Hacienda de Nueva España con notas y comentarios de Alberto M. Carreño, México, Universidad Nacional Autónoma de México, 1995.

Marichal, Carlos y Daniela Marino (comps.)

De colonia a nación. Impuestos y política en México, 17501860, México, El Colegio de México, 2001.

Marino, Daniela

"El afán de recaudar y la dificultad en reformar. El tributo indígena en la Nueva España tardocolonial”, en Marichal y MARINo (comps.), 2001, pp. 61-83.

Martínez Peláez, Severo

Motines de indios, La violencia colonial en Centroamérica y Chiapas, Guatemala, F\&G editores, 2011.

Mayagoitia, Alejandro

"Un capítulo en la formación del estado noble en la Nueva España: las dispensas de pasantía concedidas por la real y pontificia Universidad de México en el último tercio del siglo xvıII", en Soberanes Fernández y Martínez de Codes (coords.), 2008, pp. 503-532.

Mayorga García, Fernando

"La extinción del tributo indígena en la Nueva Granada", en Revista del Instituto Colombiano de Derecho Tributario, 52 (2001-2002), pp. 51-90.

Mazín Gómez, Óscar

El cabildo catedral de Valladolid de Michoacán, Zamora, El Colegio de Michoacán, 1996.

Meisel Roca, Adolfo

"La crisis fiscal de Cartagena en la era de la independencia", en Calvo Stevenson y Meisel Roca (eds.), 2011, pp. 371-403. 
Crecimiento, mestizaje y presión fiscal en el virreinato de la Nueva Granada, 1761-1800, Cartagena, Centro de Estudios Económicos Regionales, Banco de la República, 2011.

Menegus Bornemann, Margarita

"Alcabala o tributo. Los indios y el fisco (siglos XVI al XIX). Una encrucijada fiscal”, en Jáuregui y Serrano Ortega (coords.), 1998, pp. 110-130.

"Los títulos primordiales de los pueblos de indios", en MeneGUS BornemanN (coord.), 1999, pp. 137-161.

"La iglesia de los indios", en Menegus, Morales y Mazín, 2010, pp. 77-137.

Menegus Bornemann, Margarita (coord.)

Dos décadas de investigación en historia económica comparada en América Latina, México, El Colegio de México, Centro de Investigación y Estudios Sociales en Antropología Social, Instituto de Investigaciones Dr. José María Luis Mora, Universidad Nacional Autónoma de México, 1999.

Menegus, Margarita, Francisco Morales y Óscar Mazín

La secularización de las doctrinas de indios en la Nueva España, México, Universidad Nacional Autónoma de México, 2010.

Miranda, José

Las ideas y las instituciones politicas mexicanas, primera parte 1521-1820, México, Universidad Nacional Autónoma de México, 1978.

El tributo indígena en la Nueva España durante el siglo XVI, México, El Colegio de México, 1980.

Morelli, Federica

Territorio o nación. Reforma y disolución del espacio imperial en Ecuador, 1765-1830, traducción del francés de Antonio Hermosa Andújar, Madrid, Centro de Estudios Políticos y Constitucionales, 2005. 
Mörner, Magnus

La Corona española y los foráneos en los pueblos de indios de América, Madrid, Agencia Española de Cooperación Internacional, 1999.

Murra, John V.

"Did Tribute and Markets Prevail in the Andes before the European Invasion”, en LARSON y HARRIS (eds.), 1995, pp. 57-72.

Obara-Saeki, Tadashi y Juan Pedro Viqueira

El arte de contar tributarios. Provincia de Chiapas, 15601821, México, El Colegio de México, en prensa.

O’Phelan, Scarlett

“Presentación”, en Anuarios de Estudios Americanos, 68: 2 (jul.-dic. 2011), pp. 415-427.

Orellana, Sandra

The Tzutujil Mayas: Continuity and Change, 1250-1630, Norman, University of Oklahoma Press, 1984.

Orozco y Berra, Manuel

Noticia histórica de la Conjuración del Marqués del Valle. Años de 1565-1568, México, Tipografía de R. Rafael, Cadenas, 1853.

Ortiz Escamilla, Juan (coord.)

Fuerzas militares en Iberoamérica, siglos XVIII y XIX, México, El Colegio de México, El Colegio de Michoacán, Universidad Veracruzana, 2005.

Owensby, Brian P.

Empire of Law and Indian Justice in Colonial Mexico, Stanford, Stanford University Press, 2008.

"Pacto entre rey lejano y súbditos indígenas. Justicia, legalidad y política en Nueva España, siglo xviI", en Historia Mexicana, LXI: 1 (241) (jul.-sep. 2011), pp. 59-106. 
Palomeque, Silvia

"Estado y comunidad en la región de Cuenca en el siglo XIX. Las autoridades indígenas y su relación con el Estado", en BoNILLA (comp.), 1991, pp. 391-417.

Paredes Martínez, Carlos y Marta Terán (coords.)

Autoridad y gobierno indígena en Michoacán, Zamora, Michoacán, El Colegio de Michoacán, Centro de Investigaciones y Estudios Superiores en Antropología Social, Instituto Nacional de Antropología e Historia, Universidad Michoacana de San Nicolás de Hidalgo, 2003.

Peralta Ruiz, Víctor

"Fiscalidad y poder regional en el Cusco a fines de la Colonia e inicios de la República”, en Urbano (comp.), 1991, pp. 149-164.

En pos del tributo. Burocracia estatal, élite regional y comunidades indígenas en el Cusco rural, 1826-1854, Cuzco, Centro de Estudios Regionales Andinos Bartolomé de Las Casas, 1991.

"Comunidades, hacendados y burócratas en el Cusco (Perú), 1826-1854”, en Reina (coord.), 1997, pp. 53-69.

Pérez León, Jorge

"Hidalgos indianos ante la Real Chancillería de Valladolid. El caso peruano en época de los Borbones", tesis de doctorado en historia, Valladolid, Universidad de Valladolid, 2012.

“El 'imperativo nobiliario’ en Perú a finales del antiguo régimen: la prueba de hidalguía", en Chronica Nova. Revista de Historia Moderna de la Universidad de Granada, 40 (2014), pp. 277-290.

Pérez Toledo, Sonia (coord.)

Trabajo trabajadores y participación popular, Barcelona, Anthropos, Universidad Autónoma Metropolitana-Iztapalapa, 2012. 
Pietschmann, Horst

"Revolución y contrarrevolución en el México de las reformas borbónicas. Ideas protoliberales y liberales entre los burócratas ilustrados novohispanos (1780-1784)", en Caravelle, 54 (1990), pp. 21-35.

Las reformas borbónicas y el sistema de intendencias en Nueva España. Un estudio político administrativo, traducción del alemán de Rolf Roland Meyer Misteli, México, Fondo de Cultura Económica, 1996.

Plan de Juan Antonio de Riaño

Plan de Juan Antonio de Riaño, propuesto al Acuerdo para el arreglo de la real Hacienda, Guanajuato, 5 de octubre de 1808, en Hernández y Dávalos, t. I, doc. 244, en HernánDEZ SILVA (coord.).

Platt, Tristan

Estado boliviano y ayllu andino: tierra y tributo en el norte de Potosí, Lima, Instituto de Estudios Peruanos, 1982.

Pollack, Aaron

Levantamiento K'iche' en Totonicapán, 1820. Los lugares de las politicas subalternas, Guatemala, Asociación para el Avance de la Ciencias Sociales (Avancso), 2008.

“Totonicapán, 1820, ¿Una de las puntas del iceberg?”, en Pollack (coord.), 2013, pp. 189-223.

Pollack, Aaron (coord.)

La época de las independencias en Centroamérica y Chiapas. Procesos políticos y sociales, México, Instituto de Investigaciones Dr. José María Luis Mora, Universidad Autónoma Metropolitana, 2013.

Portillo Valdés, José M.

"Crisis de la monarquía y necesidad de la constitución”, en LOREnTE SARIÑ ENA (coord.), 2007, pp. 109-134. 
Quezada, Sergio y Elda Moreno Acevedo

"Del déficit a la insolvencia. Finanzas y Real Hacienda en Yucatán, 1760-1816”, en Estudios Mexicanos, 21: 2 (2005), pp. 307-331.

Real órden

Real órden de 26 de Mayo de 1810; publicada en bando de 5 de Octubre del mismo año, libertando de tributo á los indios, en Legislación mexicana o colección completa de las disposiciones legislativas expedidas desde la independencia de la República. Ordenada por los licenciados Manuel Dublán y José María Lozano [en línea] http://www.biblioteca.tv/artman2/ publish/1810_115/Real_rden_de_26_de_Mayo_de_1810_printer.shtml [consultado el 31 de enero de 2015].

Real Ordenanza

Real Ordenanza para el establecimiento é instrucción de intendentes de exército y provincia en el reino de la NuevaEspaña de órden de su magestad, Madrid, 1786 [en línea] http://babel.hathitrust.org/cgi/pt?id=nyp.33433019332356; view=1up;seq=11 [consultado el 31 de enero de 2015].

Recopilación

Recopilación de leyes de los reinos de las Indias mandadas imprimiry publicar por la magestad católica del rey don Carlos II, nuestro señor, t. II, $5^{\text {a }}$ ed., Madrid, Boix Editor, 1841, cuatro tomos. http://books.google.com.mx/books?id=428DAAAAQAAJ\& $\mathrm{pg}=\mathrm{PA} 154 \&$ source $=\mathrm{gbs} \_$toc_r\&cad $=4 \# \mathrm{v}=$ onepage \&q\&f$=$ false [consultado el 31 de enero de 2015].

Reina, Leticia (coord.)

La reindianización de América, siglo XIX, México, Siglo Veintiuno editores, Centro de Investigación y Estudios Superiores en Antropología Social, 1997.

\section{Representación}

Representación a la regencia del reino, manifestando el estado de fermentación en que se encuentra la Nueva España $y$ medio para evitar un trastorno, Valladolid, 30 de mayo de 
1810, en Hernández y Dávalos, t. II, doc. 269, en HernánDEZ Silva (coord.).

\section{Representación del Cabildo}

Representación del Cabildo de Santa Fe, capital del Nuevo Reino de Granada, a la Suprema Junta Central de España, 1809, en Almarza Villalobos y Martínez Garnica (eds.), 2008, pp. 87-117.

Representación sobre la inmunidad

Representación sobre la inmunidad personal del clero, reducida por las leyes, por el señor Abad y Queipo, Valladolid, $11 \mathrm{de}$ diciembre de 1799, en Hernández y Dávalos, t. II, doc. 261, en Hernández Silva (coord.).

Representación sobre la necesidad

Representación sobre la necesidad de aumentar la fuerza armada para mantener la tranquilidad pública, Valladolid, 16 de marzo de 1809, en Hernández y Dávalos, t. II, doc. 265, en Hernández Silva (coord.).

Romero Martínez, Adelina

"Proceso recaudatorio y mecanismos fiscales en los concejos de la Corona de Castilla", en Anuario de Estudios Medievales, 11 (1992), pp. 739-766.

Ruz, Mario Humberto

Copanaguastla en un espejo. Un pueblo tzeltal en el virreinato, $2^{a}$ ed., México, Instituto Nacional Indigenista, Consejo Nacional para Cultura y las Artes, 1992.

SAla I Vila, Nuria

$Y$ se armó el Tole Tole. Tributo indígena y movimientos sociales en el virreinato del Perú, 1784-1814, Lima, Instituto de Estudios Regionales José María Arguedas, 1996.

Samayoa Guevara, Héctor Humberto

El régimen de intendencias en el reino de Guatemala, Guatemala, Piedra Santa, 1978. 
Sánchez Albornoz, Nicolás

Indios y tributos en el Alto Perú, Lima, Instituto de Estudios Peruanos, 1978.

Sánchez Santiró, Ernest

"La irrupción del liberalismo fiscal en Nueva España. La contribución directa general y extraordinaria (1813-1815)", en América Latina en la Historia Económica, 37 (2012), pp. 9- 35.

"Los impactos fiscales de una guerra distante: crisis y restauración de la Real Hacienda en la provincia de Yucatán (18011821)", en Revista de Historia Económica, $30: 3$ (2012), pp. 323-352.

Corte de caja. La Real Hacienda de Nueva España y el primer reformismo fiscal de los Borbones (1720-1755). Alcances y contradicciones, México, Instituto de Investigaciones Dr. José María Luis Mora, 2013.

Sánchez Silva, Carlos

Indios, comerciantes y burocracia en la Oaxaca poscolonial, 1786-1860, Oaxaca, Instituto Oaxaqueño de las Culturas, Fondo Estatal para la Cultura y las Artes, Universidad Autónoma Benito Juárez de Oaxaca, 1998.

Santamaría, Daniel J.

"La propiedad de la tierra y la condición social del indio en el Alto Perú, 1780-1810”, en Desarrollo Económico, 17:66 (jul.sep. 1977), pp. 253-271.

"Recaudación y políticas tributarias en Charcas, fines del siglo XviII", en Revista de Indias, LVII: 209 (1997), pp. 885-1111.

Schaub, Jean-Frédéric

"La penisola ibérica nei secoli Xvi e xvII: la questione dello stato", en Studi Storici, 36: 1 (1995), pp. 9-49.

Schulze, Winfried

“The Emergence and Consolidation of the 'Tax State'. I. The Sixteenth Century”, en Bonney (ed.), 1995, pp. 261-279. 
Schumpeter, Joseph A.

"La crisis del Estado fiscal", en Revista Española de Control Externo, 2: 5 (2000), pp. 147-192.

Serrano Ortega, José Antonio

Igualdad, uniformidad, proporcionalidad. Contribuciones directas y reformas fiscales en México, 1810-1846, México, El Colegio de Michoacán, Instituto de Investigaciones Dr. José María Luis Mora, 2007.

“El sistema fiscal insurgente. Nueva España, 1810-1815”, en Relaciones, xxix: 115 (2008), pp. 49-83.

Serulnikov, Sergio

"De forasteros a hilicatas: una familia andina de la provincia de Chayanta, siglo xviII", en Jabrbuch für Geschichte Lateinamerikas, 40 (2003), pp. 43-70.

Silva RiqueR, Jorge

"El trabajo indígena novohispano en el siglo xviıI; un viejo problema no resuelto. Un acercamiento preliminar", en PÉREZ TOLEDO (coord.), 2012, pp. 19-37.

Silva RiqueR, Jorge (coord.)

Historia de la Hacienda Pública en Michoacán, 1786-1951. Una historia larga, México, Universidad Michoacana de San Nicolás de Hidalgo, El Colegio de San Luis, 2015.

Soberanes Fernández, José Luis y Rosa María Martínez de

Codes (coords.)

Homenaje a Alberto de la Hera, México, Universidad Nacional Autónoma de México, 2008.

Solano D., Sergio Paolo

"Padrones de población e historiografía sobre la configuración socio-racial hispanoamericana del siglo xvıI", en El Taller de la Historia, 5: 5 (2013), pp. 125-177. 
"La construcción de los censos de población del Nuevo Reino de Granada a finales del siglo xvin", en El Taller de la Historia, 7: 7 (2015), pp. 41-99.

Solórzano Pereyra, Juan

Política indiana, Madrid, Matteo Sacristán, 1736, 2 tomos.

Soux, María Luisa

“Tributo, constitución y renegociación del pacto colonial. El caso altoperuano durante el proceso de independencia (18081826)", en Relaciones. Estudios de Historia y Sociedad, 29: 115 (2008), pp. 19-48.

Spores, Ronald

The Mixtec Kings and Their Peoples, Norman, University of Oklahoma Press, 1967.

STORRs, Christopher

"Introduction: The Fiscal-Military State in the 'Long' Eighteenth Century”, en STORrs (ed.), 2009, pp. 1-22.

STORRs, Christopher (ed.)

The Fiscal Military State in Eighteenth Century European Polities, Princeton, NJ, Princeton University Press, 2009.

'T HART, Marjolein

"The Emergence and Consolidation of the 'Tax State'. II. The Seventeenth Century”, en Bonney (ed.), 1995, pp. 281-293.

Tanck de Estrada, Dorothy

Pueblos de indios y educación en el México colonial, 17501821, México, El Colegio de México, 1999.

TePaske, John J. en colaboración con José Jesús y Mari Luz

Hernández Palomo

La Real Hacienda de Nueva España: La Real Caja de México (1576-1816), México, Instituto Nacional de Antropología e Historia, 1976. 
TERÁn, Marta

“¡Muera el mal gobierno! Las reformas borbónicas en los pueblos michoacanos y el levantamiento indígena de 1810”, tesis de doctorado en historia, México, El Colegio de México, 1995. "El liderazgo indio de Valladolid, la diversidad de gobiernos en los pueblos y la política indigenista borbónica (17861810)”, en Paredes Martínez y Terán (coords.), 2003, vol. 1, pp. 361-382.

“1809. Las relaciones entre los indios y los criollos de la ciudad de Valladolid de Michoacán, en el intento de formar una junta soberana de la provincia”, en Historias, 68 (2007), pp. 33-51.

"El movimiento de los indios, de las castas y la plebe de Valladolid de Michoacán en el inicio de la guerra por la independencia, 1809-1810”, en Terán y Serrano Ortega (eds.), 2010, pp. 273-293.

Tributos tardios de la Nueva España. Programa interactivo, México, Consejo Nacional para la Cultura y las Artes, Instituto Nacional de Antropología e Historia, 2014.

Terán, Marta y José Antonio Serrano Ortega (eds.)

Las guerras de independencia en la América Española, Zamora, El Colegio de Michoacán, Instituto Nacional de Antropología e Historia, Universidad Michoacana de San Nicolás de Hidalgo, 2010.

Tilly, Charles

Coercion, Capital, and European States, AD 990-1992, Oxford, Blackwell, 1994.

URBANo, Enrique (comp.)

Poder y violencia en los Andes, Cusco, Centro de Estudios Andinos Bartolomé de Las Casas, 1991.

VAN Young, Eric

The Other Rebellion: Popular Violence, Ideology, and the Mexican Struggle for Independence, 1810-1821, Stanford, Stanford University Press, 2001. 
Vinson III, Ben

"Los milicianos pardos y la relación estatal durante el siglo xviII", en Ortiz Escamilla (coord.), 2005, pp. 47-60.

Viñuales Ferreiro, Gonzalo

"El repartimiento del 'servicio y medio servicio' de los mudéjares de Castilla en el último cuarto del sigloxv”, en Al-Qantara, XXIv: 1, (2003), pp. 179-202.

Viqueira, Juan Pedro

“Tributo y sociedad en Chiapas (1680-1712)", en Historia Mexicana, XLIv: 2 (174) (oct.-dic. 1994), pp. 237-267.

WASSERSTROM, Robert

Clase y sociedad en el centro de Chiapas, traducción de Laura Elena Pulido V., México, Fondo de Cultura Económica, 1989.

Webre, Stephen y Robinson A. Herrera (eds.)

Cultura y sociedad en Guatemala colonial, Woodstock, VT, Plumsock Mesoamerican Studies, 2014.

Wortman, Miles

Government and Society in Central America, 1680-1840, Nueva York, Columbia University Press, 1982.

Zamora Acosta, Elías

Los mayas de las tierras altas en el siglo XVI. Tradición y cambio en Guatemala, Sevilla, Diputación Provincial de Sevilla, 1985. 